\title{
ONTOGENETIC STAGES OF TREES: AN OVERVIEW
}

\author{
O. I. Evstigneev \\ Bryanskii Les' State Nature Reserve, Nerussa Station, Bryanskaya Oblast, 242180, Russia \\ E-mail:quercus_eo@mail.ru
}

\section{N. Korotkov}

Lomonosov Moscow State University, 1 Leninskiye gory, Moscow, 119991, Russia

E-mail: korotkovv@list.ru

\section{ОНТОГЕНЕТИЧЕСКИЕ СОСТОЯНИЯ АЕРЕВЬЕВ: ОБЗОР}

\author{
О. И. Евстигнеев \\ Заповедник «Брянский лес», Россия, 242180, Брянская область, Нерусса \\ E-mail:quercus_eo@mail.ru
}

\section{В. Н. Коротков}

Московский государственный университет имени М. В. Ломоносова, Россия, 119991, Москва, Ленинские горы, 1 E-mail:korotkovv@list.ru

Abstract. Based on the concept of biological age of plants, developed by Russian scientists, this paper introduces the ontogenetic stages of East European tree species. The following ontogenetic stages are distinguished within individual development of trees: seed, seedling, juvenile, immature (two subgroups), virginile (two subgroups), young generative, mature generative, old generative and senile. Detailed descriptions of ontogenetic stages are represented. Ontogenetic stages are allocated on the basis of a set of qualitative and quantitative traits of plants. Qualitative traits include the presence or absence of embryonic, juvenile, semi-adult and adult structures; ability to seed or vegetatively reproduce; ratios of the processes of growth and dying out in shoot and root systems; and shape of primary and secondary crowns. Quantitative traits include calendar age; height of aboveground parts; stem diameter at breast height $(1.3 \mathrm{~m})$ and at its base; height of stem without lower branches; length of fissuring bark on the trunk; length and width of the crown; branching order of the shoot system; length of annual shoot on the main axis and on lateral branches; number of ovules, etc. The main cenotic role of the seed stage is dispersal of the population; seedling stage - growth in a community; juvenile - adapting to growth in the ground layer; immature - adapting to the undergrowth layer; virginile - adapting to the second layer of the tree stand; generative trees - creating a cenotic environment and seed production; and senile trees - gradual release of additional resources (light, space, etc.) for the coming generation of trees.

Key words: biological age, ontogenetic stage, ontogeny, tree.

For citation: Evstigneev O.I., Korotkov V.N. Ontogenetic stages of trees: an overview. Russian Journal of Ecosystem Ecology. 2016;1(2). Available from: https://doi.org/10.21685/2500-0578-2016-2-1

Аннотация. Опираясь на концепцию биологического возраста растений, разработанную российскими учеными, статья знакомит читателя с онтогенетическими состояниями, которые выделяются в индивидуальном развитии деревьев: семена, проростки, ювенильные особи, имматурные (две подгруппы), виргинильные (две подгруппы), молодые, средневозрастные и старые генеративные, а также сенильные особи. Дана подробная характеристика онтогенетических состояний. Онтогенетические состояния выделяются на основе комплекса качественных и количественных признаков растений. К качественным признакам относятся наличие или отсутствие эмбриональных, ювенильных, полувзрослых или взрослых структур, способность индивида к семенному и вегетативному размножению, соотношение процессов новообразования и отмирания в побеговой и корневой системах. К количественным признакам относятся календарный возраст, высота надземной части, диаметр ствола на уровне 1,3 м и в его основании, высота очищения ствола от нижних сучьев, протяженность трещиноватой коры на стволе, форма, длина и ширина кроны, порядок ветвления в побеговой системе, длина годичного побега по главной оси и на боковой ветви, число семязачатков и др. Основная ценотическая роль семян - в расселении популяции, проростков - в приживании в сообществе, 
ювенильных - в адаптации к травостою, имматурных - в приспособлении к ярусу подлеска, а виргинильных ко второму ярусу древостоя, генеративных - в создании ценотической среды и в производстве семян, а сенильных - в постепенном освобождении дополнительных ресурсов (света, пространства и т.п.) для подрастающего поколения.

Ключевые слова: биологический возраст, онтогенетическое состояние, онтогенез, дерево.

Age differentiation of individuals, which is necessary for studying the structure and dynamics of populations, underlies the demography of plants. Typically, phytocoenologists carry out age differentiation by determining the calendar age [1-3]. Calendar (absolute) age is the period of astronomical time since the birth of the individual prior to the study. Through the works of T. A. Rabotnov [4] and his successors, an approach to age differentiation of individuals based on the study of ontogenesis of organisms from birth to death was grounded and developed [5-9]. This method provides division of the individual development into periods - ontogenetic stages that reflect the biological age of the plant. Applying the concept of biological age is associated with two reasons: 1) individuals of the same calendar age may be at different stages of ontogenetic development, and 2) individuals of the same ontogenetic stage may have different calendar ages [10-12]. As a rule, asynchronous development of individuals is determined by different living conditions. This means that a comparative assessment of the role of trees in the community would link more logically with level of individual development (ontogenetic stage) as opposed to cal- endar age. Beginning with L. B. Zaugolnova's works $[13,14]$, the concept of biological age has spread among Russian plant demographers who study populations of trees as well as organisation of forest communities [15-21]. However, the definition of calendar age is still dominant in forest science, and a few works in foreign literature are devoted to the problem of biological age of trees [22-24].

Article task: to acquaint the reader with the ontogenetic stages of individual growth of trees based on the concept of biological age of plants developed by Russian scientists

\section{Results}

Ontogenetic stages are common to plants of various life forms, including trees, according to the concept of biological age $[14,25-32]$. Ontogeny of different species of trees is divided into four periods and nine stages: 1) latent period (seeds); 2) pregenerative period (seedling, juvenile, immature and virginile); 3) generative period (young, mature and old); and 4) post-generative period (senile) (Table 1).

Table 1

Ontogenetic periods and ontogenetic stages of trees $[8,33]$

\begin{tabular}{|l|c|c|}
\hline \multicolumn{1}{|c|}{ Ontogenetic period } & Ontogenetic stage & Symbol \\
\hline 1. Latent & (1) Seed & $s e$ \\
\hline 2. Pre-generative & (2) Seedling & $p$ \\
\hline & (3) Juvenile & $j$ \\
\hline & (4) Immature & $\mathrm{im}$ \\
\hline 3. Generative & (5) Virginile & $g_{1}$ \\
\hline & (6) Young & $g_{2}$ \\
\hline & (7) Mature & $g_{3}$ \\
\hline 4. Post-generative & (8) Old & $s$ \\
\hline
\end{tabular}

Ontogenetic stages are allocated on the basis of a set of qualitative and quantitative traits of plants. Qualitative traits include the presence or absence of embryonic, juvenile, semi-adult and adult structures; ability to seed or vegetatively reproduce; ratios of the processes of growth and dying out in shoot and root systems; and shape of primary and secondary crowns. Quantitative traits include calendar age; height of aboveground parts; stem di- ameter at breast height $(1.3 \mathrm{~m})$ and at its base; height of the clear stem without lower branches; length of fissuring bark on the trunk; length and width of the crown; branching order of the shoot system; length of annual shoot on the main axis and on lateral branches; number of ovules, etc. $[14,33,34]$.

Individuals at different levels of vitality are allocated within each ontogenetic state. Vitality is 
the feature of plants that is manifested in the power of individuals and in different perspectives of their development [10]. As a rule, three levels of vitality are distinguished among trees: normal, sub-normal and low (sub-lethal) [29]. Vitality is associated with a variety of cenotic and environmental conditions. Groups of vitality are differentiated primarily on the basis of quantitative traits [33, 35-37].

Morphological and sometimes physiological changes of trees with different levels of vitality under transition from one ontogenetic stage to another are described in detail below.

Latent period is represented by seeds (se). The period starts with the falling of seeds from a tree and ends with their germination. Dormancy of tree seeds can be of two types: forced and inherited. Forced dormancy is characteristic of seeds that are ready to germinate, but their growth is hindered by unfavourable environmental and cenotic circumstances. This type of dormancy is marked by Acer platanoides L., Alnus glutinosa (L.) Gaertn., Betula spp., Fagus sylvatica L., Picea abies (L.) Karst., Pinus sylvestris L., Populus tremula L., Quercus robur L., Salix caprea L., and Ulmus spp. Their seeds can germinate during the fruiting season. However, seeds of Salix caprea and Populus tremula lose their ability to germinate within 1-3 months if the necessary conditions for germination are absent. Viable seeds of Ulmus spp. and Acer platanoides usually remain in the soil only until the first spring after fruiting, seeds of Fagus sylvatica - until the second and acorns of Quercus robur - until the third, while seeds of Pinus sylvestris, Picea abies, Alnus glutinosa and Betula spp. can lie viable in the soil for 5 years or more [38-40].

Inherited seed dormancy is caused by internal reasons (i.e., their maturation). In this case, the first seedlings appear only the next year after fruiting. While some seeds of Fraxinus excelsior L., Carpinus betulus L. and Tilia cordata Mill. can ripen in the soil for 6 years, seeds of Sorbus aucuparia L. can do so in 5 years, and all seeds of $M a$ lus sylvestris Mill., Acer campestre L. and A. tataricum L. germinate during the following spring [33, 41]. Thus, germination extends over some number of years in some populations of trees. It can compensate for a weak crop of seeds during some years.

Another important aspect of tree life is dissemination associated with a latent period. This allows a population to occupy the sites of release; expand its habitat area, evenly distributing the individuals in the territory and reducing intraspecific competition, away from the changed cenotic conditions; and resume participation in the cycles of vegetation succession. The seeds of many tree species are a part of a more complex structure - the diaspore. The diaspore, or germ, is a part of the plant that provides reproduction, multiplication and dissemination of species [42]. Trees with prevailing adaptations of diaspores in their dissemination agents are divided into two groups: aerochorous and zoochoric.

Diaspores of aerochorous species differ in morphology (Fig. 1) and in their method of movement through the air. The diaspore of Acer species is a mericarp presented as a samara - a fragment of fruit, formed by crushing of a syncarpous nutlet. Diaspores of Ulmus glabra Huds., Fraxinus excelsior and Betula pendula Roth are syncarpous fruits in the form of an achene with wing-like outgrowths of the pericarp [43]. This entity is also called a samara. Samaras also exist as a discoid wing from Ulmus spp. and a one-sided wing from Fraxinus $s p p$. as well as with two symmetrical wings from Betula spp. trees (see Fig. 1). Diaspores of Salix caprea and Populus tremula are seeds with a pappus of long hairs that grow from the seedstalk. An anemochorous process of dissemination of the infructescence of Tilia cordata with a wing-shaped leaf covering of the inflorescence performs the function of the diaspore as well as syncarpous walnut with the foliaceous three-lobed cupule of Carpinus betulus. Diaspores of Picea abies and Pinus sylvestris are seeds with a wing-shaped appendage formed from the surface tissues of the seed squamosa $[44,45]$. The centre of gravity of diaspores of maple, ash, hornbeam, linden, spruce and pine are shifted to one end, causing them to rotate spirally. Gravity points of diaspores of elm and birch are located close to the geometric centre. As a result, the seeds glide slowly. Gliding flight is also characteristic of willow and aspen diaspores because the centre of gravity lies below the pappus. These adaptations allow seeds of willow and aspen to fly away from a maternal tree $1-2 \mathrm{~km} \mathrm{[46];} \mathrm{spruce,}$ birch and pine seeds - $500 \mathrm{~m}$ [47-49]; hornbeam, elm and Norway maple seeds - $200 \mathrm{~m}$; ash seeds $120 \mathrm{~m}$; field maple seeds - $100 \mathrm{~m}$; and linden seeds $80 \mathrm{~m}$ [50].

According to the prevailing forms of dissemination, zoochoric species are divided into two groups: endo-zoochoric and syn-zoochoric. Sorbus aucupar$i a$ and Malus sylvestris belong to the first group. Their diaspores - juicy apples - are consumed by vertebrate animals. The majority of the seeds pass through the digestive tract undamaged [51]. Large ungulates and bears can move the seeds of apples and rowans in large quantities a distance of $1 \mathrm{~km}$. Diaspores of syn-zoochoric species (such as nuts of Fagus sylvatica and acorns of Quercus robur) are actively taken away by animals in nests or in burrows. Some part of the seed is lost, and some stocks remain unused. Small rodents can transfer acorns from the mother plant $25 \mathrm{~m}$, nuthatch $-100 \mathrm{~m}$ and common jay $-450 \mathrm{~m}$ [17]. 

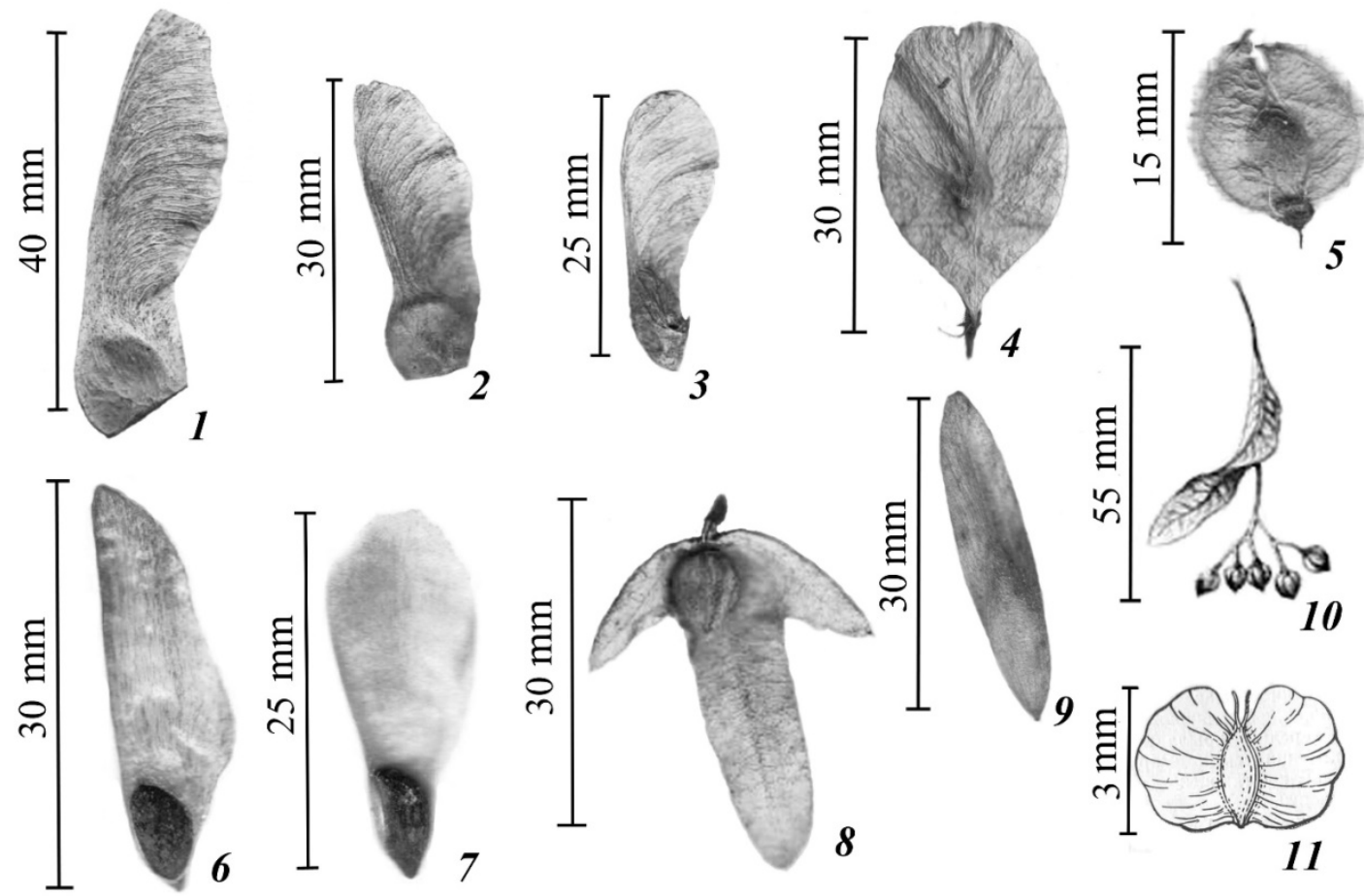

Fig. 1. Examples of diaspores:

1 - Acer platanoides; 2 - A. campestre; 3-A. tataricum; 4 - Ulmus glabra; 5 - U. laevis; 6 - Pinus sylvestris; 7 - Picea abies; 8 - Carpinus betulus; 9 - Fraxinus excelsior; 10 - Tilia cordata; 11 - Betula pendula

Pre-generative period. Four ontogenetic stages (seedling, juvenile, immature and virginile) are allocated to this period of tree life.

Seedlings or plantlets (p). These terms refer to the plants from germination to formation of the epicotyl and the first juvenile leaves. The epicotyl is the interstice between the cotyledon node and the node of the first leaves. The embryo structure cotyledons, gemmule, radicle and hypocotyl - are expressed clearly in the seedling structure. The cotyledon is the first leaf body of the plant in the seed that occurs in the apical pole of the embryo prior to formation of the plumule. The gemmule is the apical bud, first - of the embryo, and later - of the seedling. It usually contains the rudimentary epicotyl and the first leaf primordia. The hypocotyl or subcotyledonous knee is a part of the stem between the cotyledon node and the radicle [52]. Two types of seed germination - aboveground and belowground - are typical for trees.

Aboveground germination is more common among plants with relatively small seeds. The nutrients stored in the cotyledons are enough only for formation of the hypocotyl and for establishing the root in the ground. In this case, aboveground germination is more favourable when the cotyledons are quickly brought to the ground surface, turn green, begin to photosynthesise and supply the organic matter for development of the seedling. The radicle appears first. The hypocotyl then forms a loop-shaped bend that breaks the layer of soil. The meristematic tip of the shoot remains hidden be- tween the cotyledons. Protruding from the ground, the hypocotyl straightens up and pulls the cotyledons, sometimes with the seed coat. The cotyledons turn green in the light, and the gemmule encased between them gives rise to the next metameres of the primary or main shoot [53].

The appearance of the seedling from aboveground germination determines the number and shape of the cotyledons and growth characteristics of the main shoot (Fig. 2). The number of cotyledons is different in gymnosperms species: Pinus sylvestris has 4-8, Picea abies - 7-9 and Pinus sibirica Du Tour - 10-15 [54]. The cotyledons are usually linear. Dicotyledonous plants have basically two cotyledons. The shape of the cotyledons can differ: Acer platanoides and Fraxinus excelsior cotyledons are oblong-lanceolate; Carpinus betulus, Ulmus glabra and U. laevis - inversely ovoid; Fagus sylvatica - semilunar; Salix caprea - broadly elliptic; and Tilia cordata - palmate, sevenseparate (see Fig. 2).

The primary shoot may continue its development during the year of germination under good conditions from the apical bud, located between the cotyledons. Leaves of the juvenile type are formed thereafter. They differ from the adult by both form and placement on the stem. The first variant of leaf arrangement is spiral. It is characteristic of Abies sibirica, Larix sibirica Ledeb., Picea abies and Pinus sylvestris, which have numerous juvenile leaves presented as linear needles. 




Fig. 2. Seedlings:

1 - Pinus sylvestris (seedling length $-8 \mathrm{~cm}) ; 2$ - Abies sibirica $(4 \mathrm{~cm}) ; 3$ - Larix sibirica $(5 \mathrm{~cm}) ; 4$ - Carpinus betulus (5 cm); 5 - Ulmus laevis (June, $5 \mathrm{~cm}) ; 6$ - U. laevis (August, $6 \mathrm{~cm}) ; 7-U$. glabra $(6 \mathrm{~cm}) ; 8$ - Alnus glutinosa $(5 \mathrm{~cm})$; 9 - Padus avium (6 cm); 10 - Quercus robur (10 cm); 11 - Aesculus hippocastanum $(15 \mathrm{~cm}) ; 12$ - Pinus sibirica (9cm); 13 - Fagus sylvatica (9 cm); 14 - Salix caprea (May, $1 \mathrm{~cm}$ ); 15 - S. caprea (June, $4 \mathrm{~cm}) ; 16$ - Tilia cordata (May, $9 \mathrm{~cm})$; 17 - T. cordata (August, $11 \mathrm{~cm}) ; 18$ - Acer pseudoplatanoides $(15 \mathrm{~cm}) ; 19-$ A. tataricum $(14 \mathrm{~cm}) ; 20-A$. platanoides $(16 \mathrm{~cm})$; 21 - Fraxinus excelsior $(15 \mathrm{~cm}$ ). Designations: $a b$ - apical bud, $b$ - border between hypocotyl and root, $c$ - cotyledon, $e$ - epicotyl, fjl - first pair of juvenile leaves, fojl - fourth pair of juvenile leaves, $f z$ - fuzz formed from epidermal cells of hypocotyl, $h$ - hypocotyl, $j l$ - juvenile leaves (needles), lr - lateral root, pr - primary root, ps - peel of seed, sjl - second pair of juvenile leaves, $t j l$ - third pair of juvenile leaves. Sources and the authors of figures: 1 - N. A. Tatarenkova; 2-4, 10, 12, 13, 16, 18, 19 - [55]; 5 - [56]; 6, 7 - [57]; 8 - K.V. Belyakov; 9 - [58]; 11, 17 - O. I. Evstigneev; 14, 15 - [59]; 20, 21 - [60] 
The second variant is alternate leaf phyllotaxy a special variant of spiral. It is characteristic of $\mathrm{Al}$ nus glutinosa, Betula pendula, Carpinus betulus, Salix caprea and Tilia cordata. Seedlings of these species can generate up to five juvenile leaves in the light, but only one in the shade. Juvenile leaves of Tilia cordata are unlike adults - oblong-ovate, sometimes with three lobes; Betula pendula - pubescent, ternate and laciniate, with a serrated edge; and Carpinus betulus and Alnus glutinosa - ovate, short-pointed at the apex. The third option of leaf arrangement is opposite. Two groups of species are allocated here. The first group includes Fagus sylvatica, Salix alba L., S. fragilis L., Ulmus glabra and $U$. laevis. For these species, juvenile-type leaves are arranged oppositely, but adult leaves alternately. The other group of species includes Acer campestre, A. platanoides, A. pseudoplatanoides L., A. tataricum and Fraxinus excelsior. All leaves (juvenile and adult) of these species are arranged oppositely. The form of juvenile leaves of A. campestre is broadly ovate, while those of A. tataricum and $A$. pseudoplatanoides are ovoid. E. A. Kondrat'eva-Mel'vil' [60] described for Acer platanoides and Fraxinus excelsior several variants of juvenile leaves. The first pair of juvenile leaves of A. platanoides seedlings that belong to the epicotyl is large and widely ovoid; the second pair - underdeveloped and scale-shaped, located on a shortened metamere; and third and fourth pairs - small and palmatilobate (see Fig. 2,20). The first pair of juvenile leaves of $F$. excelsior seedlings has one foliole, second pair - scale-shaped leaves that develop on the shortened metamere and third pair - compound leaves with three folioles (see Fig. 2, 21). The second pair of leaves of $A$. platanoides and $F$. excelsior cannot form a complete leaf plate because it is laid and formed during the intensive growth of the root and the active development of the first pair of leaves [60]. In light deficiency, visible growth of the apical bud is delayed until the end of the growing season; maple seedlings remain with one pair of broadly ovoid leaves and ash with a pair of simple oblong-lanceolate leaves.

Seedlings are fairly shade tolerant because the leaves form a shadow structure and photosynthesise in low light. Among a number of tree species, a shadow juvenile leaf structure is maintained even in the light. This indicates that the feature is secured genetically $[13,34]$. The duration of the seedling stage for trees with aboveground germination is determined by the interval of time from germination to when the cotyledons die off and is usually limited to the first growing season [33].

Underground germination is more common among trees with large seeds (e.g., Quercus robur and Aesculus hippocastanum L.). Seeds of these plants are stocked up actively by rodents in soil burrows. In these circumstances, underground germination is more favourable when the cotyledons do not protrude from the surface. Seedlings have special adaptations with respect to germination. Like all woody plants, when oak germinates, the main root and hypocotyl start to grow initially. However, the hypocotyl does not bend like in aboveground-germinating plants and is not deepened by pushing the root into the lower layers of the soil. The hypocotyl length of formed seedlings can reach $15 \mathrm{~cm}$ [61]. Adventitious roots are formed thereafter. The primary shoot appears from the germinal plumule after that (see Fig. 2, 10, 11). It greatly expands and raises the gemmule, actively breaking through the soil; the first 7-9 leaves after cotyledons appear in the form of flakes, which are closed, and protect the growth cone during underground growth in the early development of the seedling. Due to the high turgor of flakes growing, the shoot tip becomes sharp, becoming easily able to pierce the soil [53]. Sometimes oak seedlings that grow from acorns, stored by animals deep in burrows, are not able to immediately break through a thick layer of soil; in this case, a strongly crooked stem is formed and may appear on the surface only after 2 years. At this time, seedlings are powered at the expense of cotyledons. O. B. Mikhalevskaya [62] showed that under these conditions, the cotyledons lose up to $80 \%$ dry weight. The duration of the seedling stage (from the beginning of germination to before green, assimilating leaves) of young oaks that emerge from acorns lying under litter is not more than 6 weeks [63]. These individuals spend significantly less nutrients during germination. Dead cotyledons can be stored up to 8 years after the formation of green, assimilating leaves of young oak. However, the cotyledons do not perform their function and therefore cannot serve as a sign that differentiates the seedling from juvenile stages.

Juvenile plants (j). This group of plants does not extend beyond herbaceous cover. The height of individuals usually does not exceed $50 \mathrm{~cm}$ [33]. The function of these plants is to gain a foothold in the community and to adapt to it. With a shift to the $j$ stage, the cotyledons fall off. However, in some species, the cotyledons that have fulfilled their function can remain on the plant (e.g., oak and chestnut). In this case, the transition to the $j$ stage is associated with the appearance of green leaves with a developed plate (Fig. 3, 13, 18). The structure of $j$ individuals is simple. They are small, single-axis, unbranched plants with leaves of $j$ type. For example, $j$ oak leaves, unlike adults, are elongated and obovate, with few side lobes and a wedge-shaped base. 
The $j$ plants have one elongated shoot that can consist of 2-7 1-year increments. Trees are divided into monopodial and sympodial groups according to a manner of shoot growth. A manner of growth is fixed genetically, as is revealed in the conditions of free growth in full light. Under monopodial growth, annual increments of plants are formed as a result of activity of the same apical meristem. This growth is typical of conifers - Abies sibirica, Juniperus communis L., Picea abies, Pinus sibiri$c a, P$. sylvestris, etc. - as well as some deciduous trees - Acer spp., Fraxinus excelsior, Malus sylvestris, Quercus robur, Sorbus aucuparia, etc. Under sympodial growth, annual increments are generated by the activities of different apical meristems. The apical bud of the main (primary) shoot dies, and monopodial growth of the first-order axis stops usually at the beginning of the second growing season (e.g., Tilia cordata, Carpinus betulus, Betula spp., Populus spp. and Salix spp.), but sometimes at the beginning of the third season (e.g., Ulmus spp.). Nevertheless, the formation of the vertical stem continues typically due to the side bud just above and nearest to the dead one. Replacement of the central apical shoot by a lateral shoot is repeated annually. As a result, the stem becomes a sympodium, consisting of several shoots that are formed by different apical meristems. External traces of such growth are clearly visible in $j$ plants in the form of a dried top or a scar from a dead bud (see Fig. 3, 6, 8).

The basal section of the stem lies flat and roots itself in some $j$ individuals (see Fig. 3, 22). The horizontal part is represented by the hypocotyl and a few increments of subsequent years [26, 58]. Lodging of the stem is determined by the weak development of mechanical tissues and ease of rooting in moist litter associated with high meristematic activity of $j$ plants [64]. The share of the lying-down $j$ individuals of Fraxinus excelsior, Tilia cordata and Acer campestre is considerable and makes up 50-80\% [13, 14, 27, 34]. This is not by accident. Due to the contractility of adventitious roots, the plagiotropic part of the stem is retracted into the soil to a depth of $1 \mathrm{~cm}$. At the same time, rodents cover shoots by emissions from their burrows. As a result, the horizontal sections appear at a depth of $3.5 \mathrm{~cm}[65,66]$. Because of this, plants form additional adventitious roots, develop a larger volume of soil and become more fixed in the community.

The $j$ individuals are more shade tolerant than individuals of subsequent ontogenetic stages. Determination of the minimum light required showed that Acer platanoides can exist at $0.3 \%$ of sunlight; Fraxinus excelsior and Acer campestre - at $0.4 \%$; Tilia cordata - at $0.6 \%$; and Picea abies at $1.0 \%$ [67]. The ability of $j$ plants to live in low light is determined by two factors: 1) the shadow structure of leaf blades and needles in which the low density diffused light is used most completely and 2) the fact that under a forest canopy, the individuals form a short length of annual increment in height. For example, the annual increment length is $10.0 \mathrm{~cm}$ in $j$ individuals of Acer platanoides in full light, but only $0.3 \mathrm{~cm}$ in the case of light deficit. This indicates that the main flow of organic substances is directed not to growth, but to the supportive respiration in light-deprived plants. At the same time, needle length and area of leaf blades are increased. Plant physiologists believe that through these adaptations, plants are able to maintain a positive balance of photosynthesis products under a lack of light for an extended duration $[68,69]$. These adaptations allow Picea abies $j$ individuals to live under the forest canopy with minimum light for 6 years; Fraxinus excelsior individuals - up to 7 years; Acer platanoides and Tilia cordata - up to 10 years; and $A$. campestre - up to 13 years. Plants die, if light conditions do not improve after that age.

The mechanism of death of $j$ undergrowth beneath the canopy in low light is the same for all tree species. Let us consider this. Positive balance of organic matter is necessary for normal development of undergrowth, when organic substances are formed more during photosynthesis than are spent on respiration [68-71]. Under these conditions, plant growth is possible: the emergence of branches of new orders in the shoot system and new roots leads to an increase in the absorption surface. This facilitates the transition of individuals in the subsequent ontogenetic stage. However, a positive balance of the organic substances steadily decreases with age at constant light deficiency because the proportion of respirable parts - roots and stems - increases $[68,72]$. Analysis of age changes of the mass ratio of photosynthetic and nonphotosynthetic parts in $j$ individuals grown in low light under the canopy showed that the proportion of leaves decreases and the proportion of axial (respiratory) parts increases with calendar age (Fig. 4). Reduction of the share of leaves impacts negatively the balance of organic substances. Net assimilation decreases in the limited flow of light (Fig. 5). As a result, a point occurs during the life of the $j$ individual, when the balance becomes zero or negative. Zero balance of organic matter corresponds to the compensation point on the light curve of productivity of the organism [72-74]. In this case, all organic substances produced during photosynthesis are absorbed by respiring organs, and it is not enough for the further development of plant. At this point, growth processes are extinguished; the annual increments in height decrease, and plants are exhausted and die. This mechanism of reduction of an individual $j$ plant's vitality and then its death reflects the general regularity of undergrowth development for all ontogenetic stages under the forest canopy with minimum light [75]. 


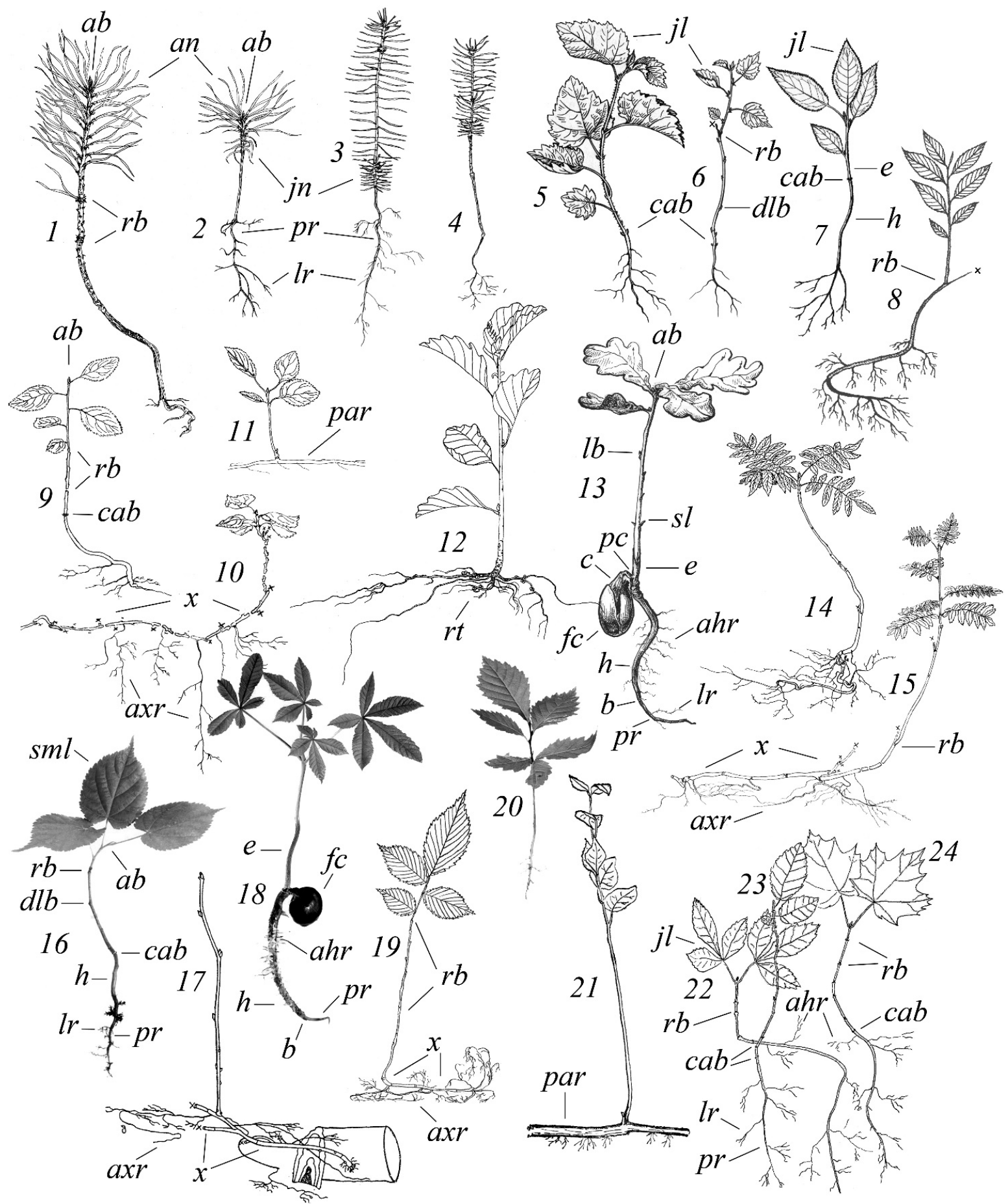

Fig. 3. Juvenile plants:

1, 2 - Pinus sylvestris with normal (height $-15 \mathrm{~cm})$ and low $(9 \mathrm{~cm})$ vitality; 3, 4- Picea abies with normal $(11 \mathrm{~cm})$ and low (11 cm) vitality; 5, 6- Betula pendula with normal $(12 \mathrm{~cm})$ and low $(9 \mathrm{~cm})$ vitality; 7-Padus avium (12 cm);

8 - Salix pentandra $(18 \mathrm{~cm}) ; 9,10,11$ - Malus sylvestris of seed origin $(8 \mathrm{~cm})$, on xylorrhizoma $(12 \mathrm{~cm})$

and root-borne shoots ( $6 \mathrm{~cm}) ; 12$ - Alnus glutinosa $(20 \mathrm{~cm}) ; 13$ - Quercus robur $(17 \mathrm{~cm}) ; 14,15$ - Sorbus aucuparia of seed origin $(20 \mathrm{~cm})$ and on xylorrhizoma $(25 \mathrm{~cm}) ; 16,17$ - Tilia cordata of seed origin (14 cm) and on xylorrhizoma

$(17 \mathrm{~cm}) ; 18$ - Aesculus hippocastanum $(30 \mathrm{~cm}) ; 19$ - Ulmus glabra on xylorrhizoma $(24 \mathrm{~cm}) ; 20-U$. laevis of seed origin (14 cm); 21 - Populus tremula of root-borne shoot origin $(25 \mathrm{~cm}) ; 22$ - Fraxinus excelsior $(7 \mathrm{~cm}) ; 23$ - Carpinus betulus $(10 \mathrm{~cm}) ; 24$ - Acer platanoides $(10 \mathrm{~cm})$. Designations: ahr - additional roots formed on hypocotyl, an - adult needle, axr - additional roots formed on xylorrhizoma, cab - buds located in the axils of cotyledon, dlb - dormant

lateral buds, $f c$ - fruit coat, jn - juvenile needle, $l b$ - lateral buds, par - root of parent plant, $p c$ - petiole of cotyledon, $r b$ - ring bud, $r t$ - root tubercle, sl - squamous leafs, sml - semi-mature leafs, $x$ - xylorrhizoma.

Crosses - residuals of dying tops of shoots. Other designations: see Fig. 2. Sources and the authors of figures: 1, 2 - N. A. Tatarencova; 3, 4 - [36]; 5, 6 - [65]; 7 - [58]; 8 - [32]; 9-11, 14, 15 - A. S. Brok-Volchansky; 13 - G. V. Shut; 12 - K. V. Belyakov; 16, 18, 20, 21, 22, 23, 24 - O. I. Evstigneev; $17-[34] ; 19-[66]$ 


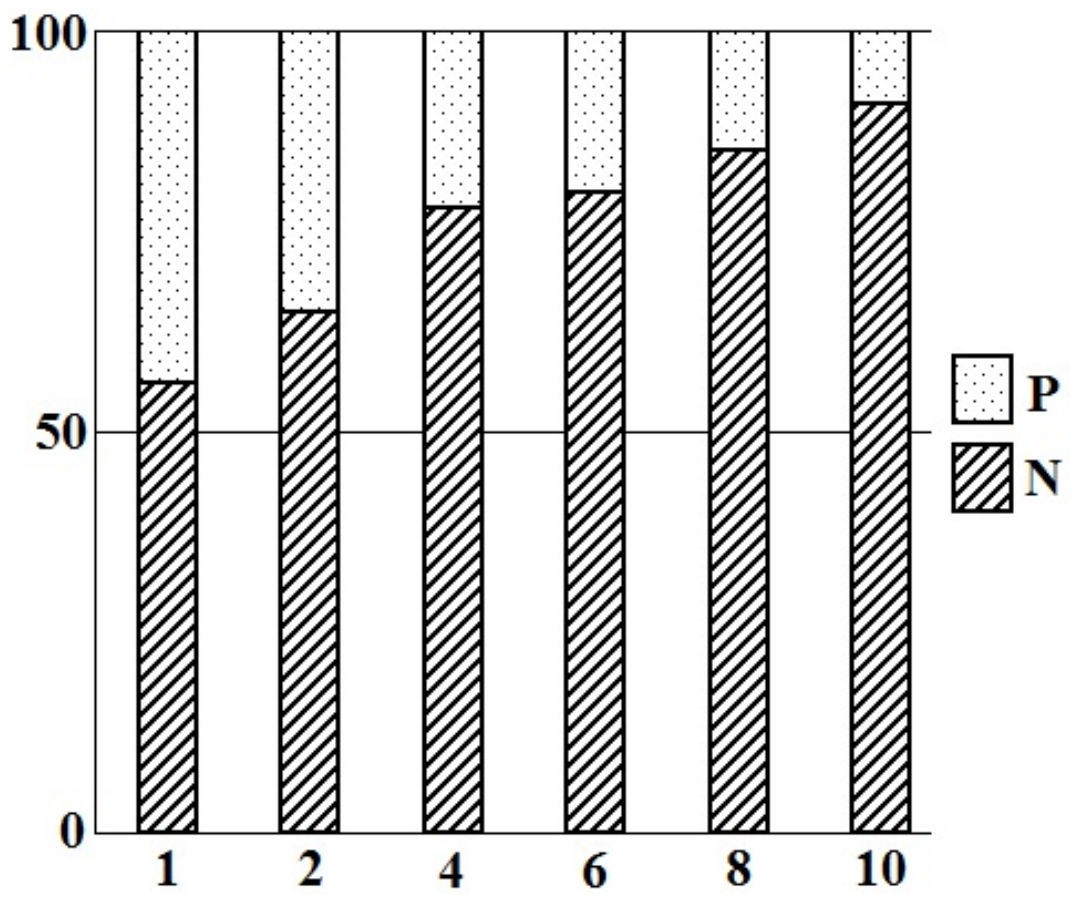

Fig. 4. Mass ratio of photosynthetic $(\mathrm{P})$ and non-photosynthetic $(\mathrm{N})$ parts of juvenile individuals of Acer platanoides grown under a dense forest canopy at a light intensity $0.3 \%$ of total illumination [76].

Vertical axis - mass ratio, \%; horizontal axis - absolute age, years

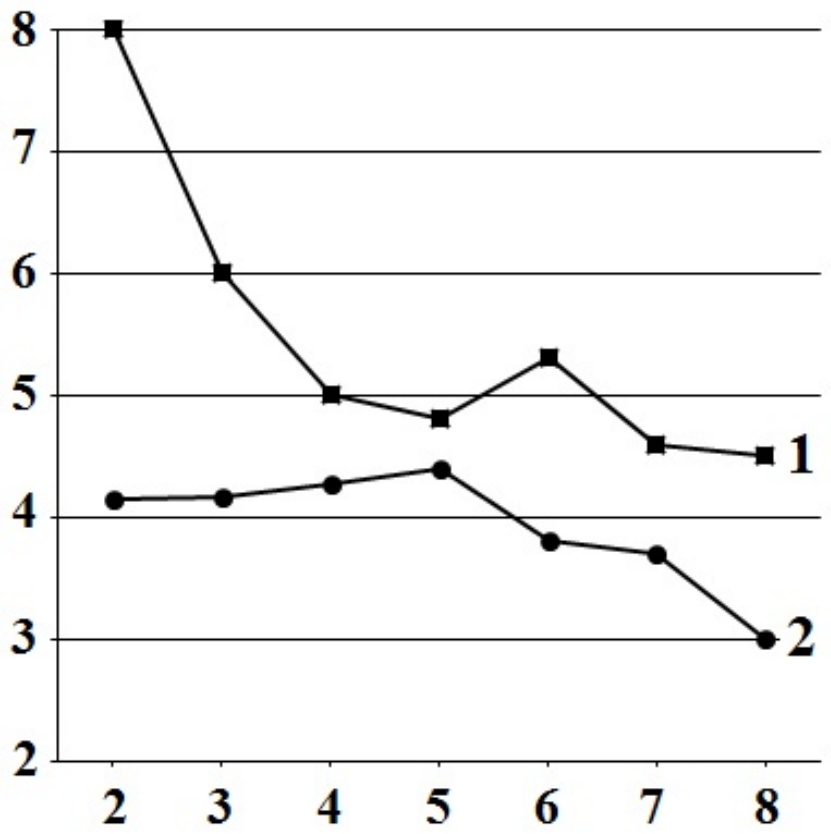

Fig. 5. Net assimilation of juvenile individuals of Carpinus betulus (1) and Ulmus glabra (2) under a forest canopy with limited illumination [75]. The illumination in the C. betulus habitat was $0.7 \%$ of total illumination, in the U. glabra habitat - $0.5 \%$. Vertical axis - net assimilation, $\mathrm{mg} \mathrm{cm}^{-2}$ year; horizontal axis - absolute age, years

The $j$ plants may have different origins: seed and vegetative. Seed plants are described above. Vegetative individuals are formed on xylorrhizomas or on the roots. A xylorrhizoma is a perennial lignified rhizome [77]. Trees form two variants of xylorrhizomas: hypogeogenic and epigeogenic [34, 58]. Hypogeogenic xylorrhizomas develop from dormant buds located on the belowground shoots (see Fig. 3, 17). Epigeogenic xylorrhizomas are presented by branches and shoots that are lying down, are covered by litter and are rooted (see Fig. 3, $10,15,19,22)$. Monoaxial aboveground shoots are $j$ individuals of vegetative origin that arise from dormant buds of xylorrhizomas during the first year. Leaves of $j$ or semi-adult types are formed on these shoots. Individuals of xylorrhizoma origin are characteristic of Acer campestre, A. tataricum, Alnus glutinosa, Carpinus betulus, Fraxinus excel- 
sior, Malus sylvestris, Padus avium Mill., Sorbus aucuparia, Tilia cordata, Ulmus spp., etc. The duration of the $j$ stage of xylorrhizoma plants is usually shorter than that of individuals of seed origin [33].

Root-borne shoots arising from adventitious buds on horizontal roots are located usually near the soil surface (see Fig. 3, 11, 21). A frequent cause of their formation is trauma. Such regenerative shoots are characteristic of most trees, with the exceptions of Quercus robur, Fagus sylvatica, Fraxinus excelsior and coniferous trees [78]. Shoots that appear without damage to roots are uncommon for Populus tremula, Cerasus avium (L.) Moench and Ulmus spp. These root-borne shoots are called propagative (propagatio - reproduction). Trees of this group form greater numbers of shoots after root injury. The cenotical purpose of propagative shoots is to strengthen the position of the population in the community. Sometimes, the proportion of root shoots can be significant in the vegetative progeny $-60-100 \%$ [79]. Juvenile individuals of root shoot origin, as well as seed origin, are monoaxial. However, these individuals do not have a hypocotyl section, and the length of the shoot that develops from adventitious buds reaches high values (e.g., at about $1 \mathrm{~m}$ from $P$ ориlus tremula) (see Fig. 3, 21). Root-borne shoots of aspen carry leaves of $j$ type - ovate with a cordate base and serrulate margins. Adventitious buds rarely appear one by one; they often form groups that develop up to 12 shoots. Later, only one shoot is saved while the others die $[80,81]$. Part of the parent root, which is located after the root-borne shoot, is usually thicker. This is because the products of assimilation arrive from adult plants and from shoots [78]. The $j$ individuals of vegetative origin (from xylorrhizomas and from roots) have adventitious root systems. During the $j$ stage, the adventitious root system is usually small, and $j$ individuals begin the next ontogenetic stage in a year or two.

Individuals of vegetative origin advance through the same ontogenetic stages as do individuals of seed origin. This is because individuals of vegetative origin have similar sizes and pace of development as plants that grew from seed after one or two ontogenetic stages [26, 27, 33].

Immature plant (im). These plants begin their active resource development in the herb layer and above it. Therefore, branching of shoots and crown formation start. Acrotonous branching is characteristic of trees when the largest lateral branches are formed closer to the top of the parent shoot. Axillary buds of the upper nodes are more developed at the annual shoot. The most powerful elongated growth shoots are formed from these buds during the following year. A part of the lower buds on the annual shoot is dormant [65]. A tree can occupy the greatest amount of air space and provide light for leaves with such branching.

The main axis (stem) is formed by monopodia in monopodially growing plants and by sympodia in sympodially growing plants. A monopodium is a perennial axial plant organ formed as a result of the same apical meristem, while a sympodium is a perennial axial plant formed as a result of successive apical meristems. Stems are usually taken as the first order of branching and the side shoots as the second. Immature individuals are divided into two subgroups according to the developmental degree of the shoot and root systems.

Immature plants of the first subgroup ( $\left.\mathrm{im}_{1}\right)$. These plants are located in the herb layer. Continuous grazing of numerous wild ungulates is a significant natural factor that always influences the formation of $\mathrm{im}_{1}$ individuals in the herb cover, as the animals damage undergrowth. Grazing by domestic animals can be added to this factor with the appearance of agriculture. As a result, trees are usually long delayed in the $\mathrm{im}_{l}$ stage.

Oak undergrowth can spend 16 years and hornbeam undergrowth 17 years in herb cover at forest edges and in glades. However, the young trees are preparing to exit from herb cover during this time: they create extensive shoot and root systems. Infant crowns with axes of the second and third order are formed (Fig. 6). The length of annual shoot on the leader axis is generally equal to the length of the lateral shoot. Therefore, the differentiation of shoots on the leader axis and lateral branches sometimes is not visible, especially during the middle and at the end of the ontogenetic stage. At this point in time, the shape of the crown resembles an umbrella (see Fig. 6, 7, 10, 11). Mostly leaves of the semi-adult type are formed on shoots. They can be distinguished from juvenile leaves by plate form. For example, semi-adult leaves of Tilia cordata are oblong-ovate, of Quercus robur - narrowly obovate, with 3-4 pairs of lateral lobes, and of Alnus glutinosa - widely rounded, with a notch at the top of the leaves. Complex leaves of Fraxinus excelsior consist of 7, 9 or 11 folioles.

Leaf area of semi-adult types is usually more than that of adult leaves. This is because $\mathrm{im}_{1}$ individuals are formed in the lower layer of communities where solar radiation is limited. Broad leaf blades allow capturing scattered light of low density with a larger area. This ontogenetic trait is fixed genetically, as it is manifested in $\mathrm{im}_{l}$ individuals in different cenotic conditions - at the edges and under the forest canopy. Researchers have noted that the anatomy of leaves of $i m_{l}$ individuals still retains the shadow structure [34, 82], in which faint light is used efficiently for photosynthesis [69]. 


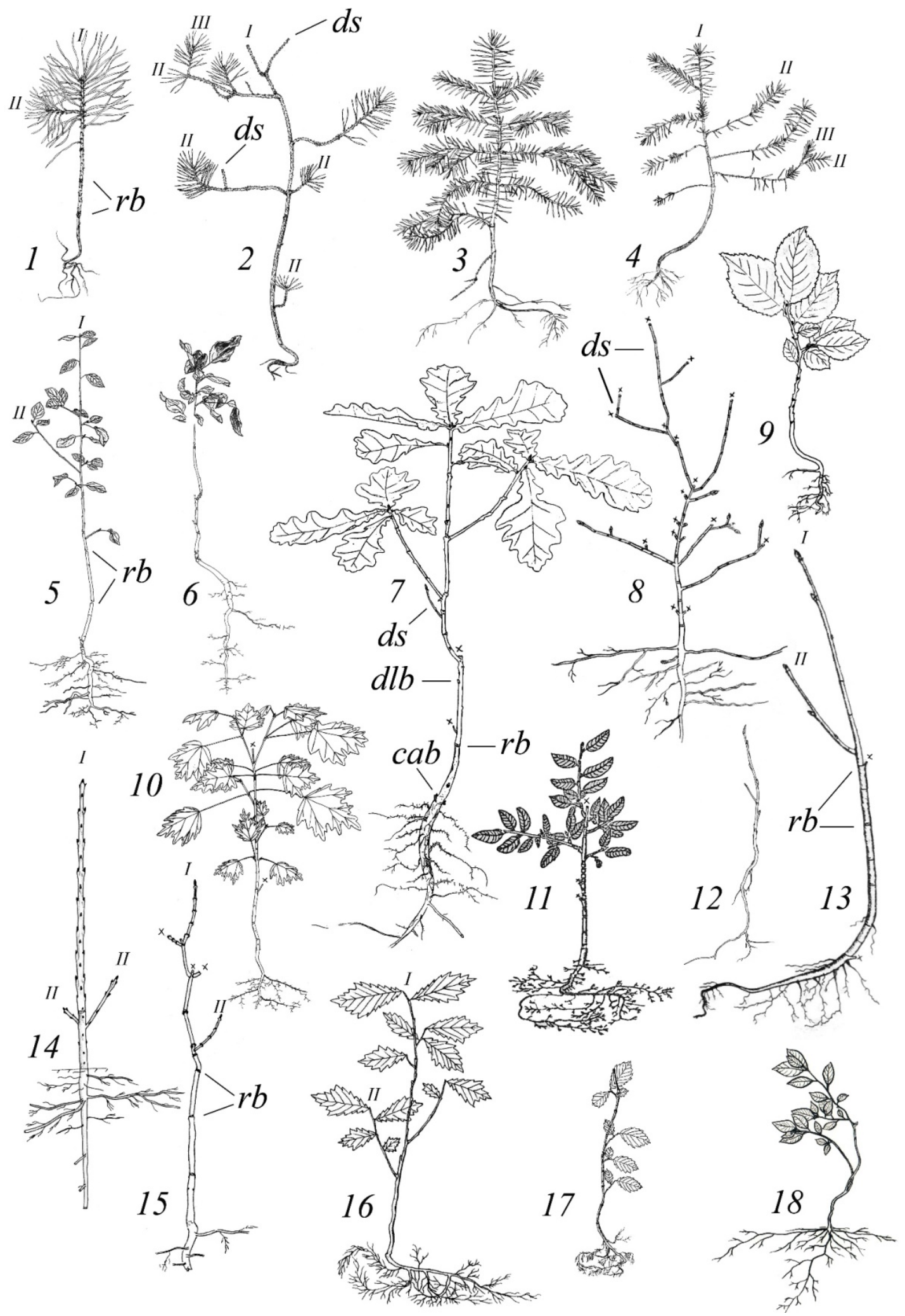

Fig. 6. Immature plants of first subgroup: 1, 2 - Pinus sylvestris with normal (height $-20 \mathrm{~cm}$ ) and low $(40 \mathrm{~cm})$ vitality; 3, 4- Picea abies with normal $(40 \mathrm{~cm})$ and low $(37 \mathrm{~cm})$ vitality; 5, 6- Malus sylvestris with normal $(43 \mathrm{~cm})$ and low (34 cm) vitality; 7 - Quercus robur (50 cm); 8 - Acer platanoides (35 cm); 9 - Carpinus betulus $(17 \mathrm{~cm})$; 10 - Acer campestre (forest, $45 \mathrm{~cm}) ; 11$ - Fagus sylvatica $(46 \mathrm{~cm}) ; 12$ - Betula pendula $(16 \mathrm{~cm}) ; 13$ - Tilia cordata (forest, $33 \mathrm{~cm}) ; 14,15$ - Fraxinus excelsior with normal $(35 \mathrm{~cm})$ and low $(38 \mathrm{~cm})$ vitality; 16, 17 - Ulmus glabra with normal $(48 \mathrm{~cm})$ and low $(27 \mathrm{~cm})$ vitality; 18 - Salix caprea $(35 \mathrm{~cm})$. Designations: $d s$ - dead shoot; I, II, III - shoot of first, second and third branching order. Other designations: see Figs. 2, 3. Sources and the authors of figures: 1, 2 - N. A. Tatarenkova; 3, 4- [36]; 5, 6 - A. S. Brok-Volchansky; 7 - M. D. Maksimchuk;

8, 15 - O. I. Evstigneev; 9 - T. V. Kishenkova; 10 - A. V. Korotkova; 11, 13 - [26, 34, 83]; 12 - N. I. Lysikh; $14-$ V. N. Korotkov; 16, $17-[66] ; 18-[32]$ 
Undergrowth in the $\mathrm{im}_{1}$ stage is characterised as highly shade tolerant. However, these plants need more light for survival under the forest canopy compared to juvenile individuals. For example, the light minimum of $\mathrm{im}_{1}$ Acer platanoides plants is $0.4 \%$; Fraxinus excelsior and $A$. campestre $-0.5 \%$; Tilia cordata - $0.7 \%$; and Picea abies - $1.1 \%$. Some weakening of shade tolerance of $i m_{1}$ undergrowth is associated with an increase in the share of respiratory parts (stems and roots) in the total biomass of the plants $[67,76]$.

Several morphological adaptations to low light are observed in $\mathrm{im}_{1}$ individuals in addition to those identified in $j$ plants. First, individuals with greater branching order are formed in conditions of minimum light: Acer campestre and Pinus sylvestris form only second-order branches during free growth in full light, but individuals with a thirdorder branch appear under the forest canopy. An increase of branching order is a type of compensatory mechanism that allows individuals to increase the number of assimilating shoots in the crown under illumination deficiency. Second, substantial shading defines replacement of the central apical shoot by a lateral shoot in the shoot system. This is caused by the cenotic condition, not genetics, because it is expressed similarly for monopodially growing trees and for sympodially ones in conditions of light deficiency. Here, the apical bud and a part of the leader shoot are dying. Lateral branches functionally replace the main axis, and the stem becomes tortuous (see Fig. 6, 2, 4, 8, 15, 18). Replacement of the central apical shoot by the lateral shoot is a result of the negative balance of organic matter; when produced during photosynthesis, organic substances are insufficient for shoot respiration. Such abruption of plant parts apparently promotes longer maintaining of a positive balance and, therefore, elongation of undergrowth life beneath the forest canopy. As a result, $i m_{1}$ individuals of Picea abies under light starvation can live up to 10 years; Acer platanoides and Fraxinus excelsior - up to 17 years; and A. campestre and Tilia cordata - up to 18 years [76]. After these ages, undergrowth dies, if the treefall gap in the forest canopy is not formed.

Immature plants of the second subgroup $\left(\mathbf{i m}_{2}\right)$. At edges and in meadows and forest clearings, the task of $\mathrm{im}_{2}$ undergrowth is to quickly escape the herb layer and the zone of clipping by ungulates. This problem is solved by trees in different ways.

Immature undergrowth of Malus sylvestris and Pyrus communis L. at edges and in glades is under constant pressure from herbivores, and these plants can 'sit' in the herb cover for up to 15 years. The plants form extensive shoot and root systems and create conditions for a quick exit from the clipping zone during this time. The leading shoot is developed from dormant buds in the basal part of the stem in $\mathrm{im}_{2}$ individuals (Fig. 7, 7, 8). This rejuvenated shoot is distinguished by enhanced growth and large size (length is up to more than $1 \mathrm{~m}$ per year). Lateral shoots appear during the second year. As a result, the height of apple and pear becomes about $4 \mathrm{~m}$ for 3 or 4 years; the crown is thus quickly removed from the clipping zone of ungulates. A similar method of crown formation on the edges and in glades was observed in single individuals of Sorbus aucuparia.

The method of escape from the clipping zone occurs differently for undergrowth of Acer platanoides, Quercus robur, Populus tremula, Ulmus glabra, etc., which belong to forest plants. 'Accumulating forces' in $\mathrm{im}_{1}$-stage, the plants escape the herb cover quickly due to the development of a powerful shoot from a bud, which is located on the top or upper part of the stem (see Fig. 7, 5, 9-11). These shoots are also characterised by intensive growth and considerable size. Their length for 1 year could reach $1 \mathrm{~m}$ or more. As a result, undergrowth height reaches $4-5 \mathrm{~m}$ for 3 or 4 years after leaving the herb cover.

Thus, deciduous trees implement the same result (a quick exit from the clipping zone) by deploying various buds: edges species form their shoot from dormant buds located at the base of the stem, and forest species shoot development results from the most powerful bud located at the top of the stem. Because the length of the current increment of $\mathrm{im}_{2}$ individuals in height in bright locations (i.e., treefall gaps, edges and glades) is many times greater than the lateral increment, the upper part of the crown, which overlooks herbs, becomes narrow, cylindrical and elongated in the vertical direction. The lower part of the crown is usually broad because it is an artefact of the umbrellashaped crown of $\mathrm{im}_{1}$ individuals that was formed in the herb cover (see Fig. 7).

It is known that Picea abies and Pinus sylvestris undergrowth as food is not as attractive to ungulates as is undergrowth of deciduous trees [84-87]. Coniferous species do not need to leave quickly the ungulate clipping zone. The height of growth of spruce and pine during the $\mathrm{im}_{2}$ stage is small $(10-20 \mathrm{~cm})$ in comparison with deciduous trees, and it is comparable to the increment of lateral axes. For this reason, the height of $\mathrm{im}_{2}$ undergrowth is no more than $1 \mathrm{~m}$, and the shape of the crown is widely cylindrical or widely conical (see Fig. 7, 1, 3). 


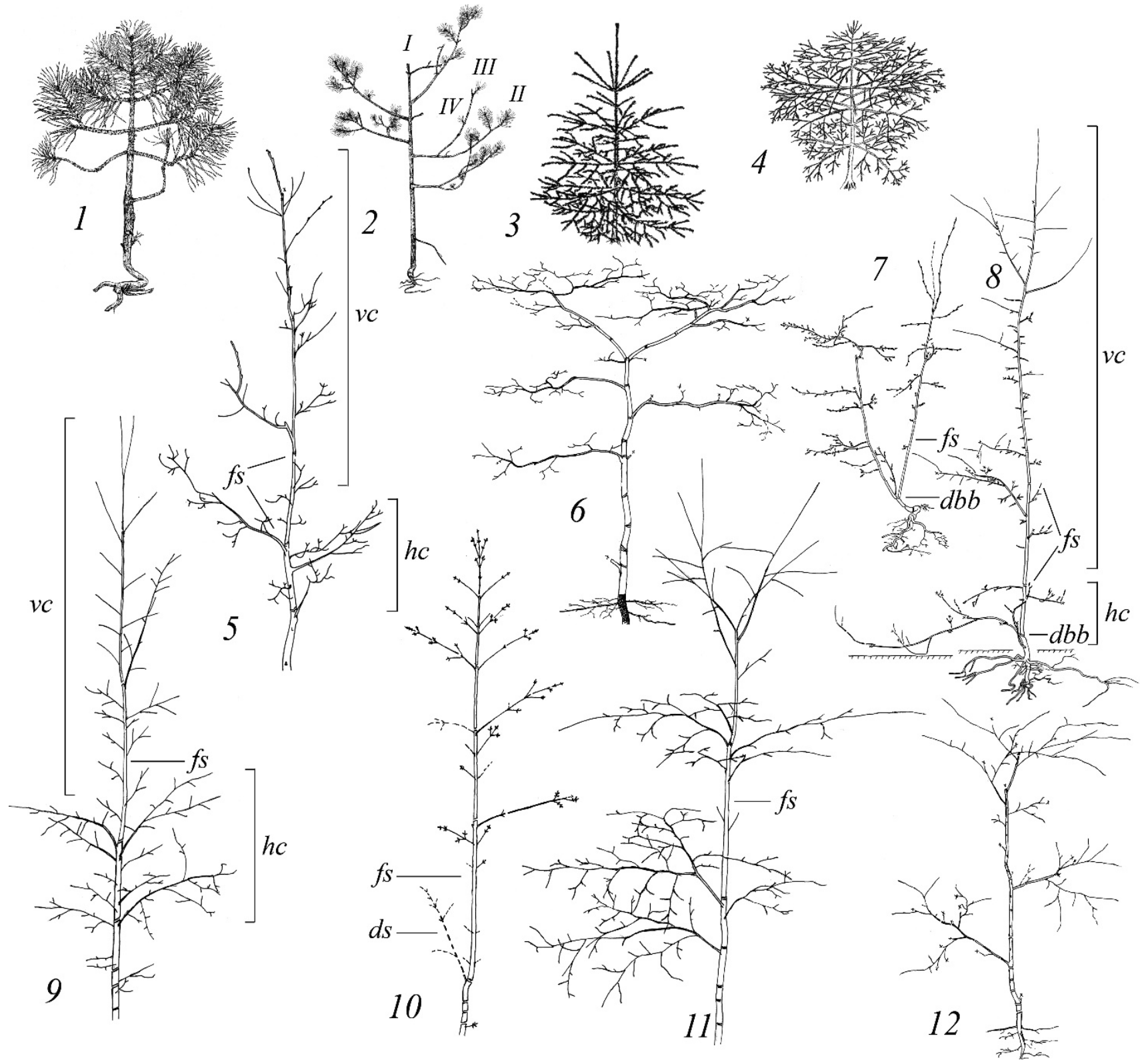

Fig. 7. Immature plants of the second subgroup:

1, 2 - Pinus sylvestris with normal (height - $0.7 \mathrm{~m}$ ) and low $(0.7 \mathrm{~m})$ vitality; 3, 4 - Picea abies with normal (0.7 $\mathrm{m})$ and low (0.6 m) vitality; 5, 6 - Quercus robur with normal $(3.0 \mathrm{~m})$ and low $(2.0 \mathrm{~m})$ vitality; 7, 8 - Malus sylvestris with normal vitality at the beginning $(1.3 \mathrm{~m})$ and in the middle $(2.8 \mathrm{~m})$ ontogenetic stage; 9 - Populus tremula (4.0 $\mathrm{m}$ ) with normal vitality; 10 - Acer platanoides (3.5 m) with normal vitality; 11,12 - Ulmus glabra with normal ( $4.0 \mathrm{~m}$ ) and low $(2.0 \mathrm{~m}$ ) vitality. Designations: $d b b$ - location of dormant bud in the basal part of the stem (forming shoot was formed from the dormant bud); fs - forming shoot; hc - the lower part of the crown elongated

in the horizontal direction; $v c$ - the upper part of the crown elongated in the vertical direction;

I, II, III, IV - shoot of first, second, third and fourth branching order. Other designations: see Fig. 6. Sources and the authors of figures: 1, 2 - N. A. Tatarenkova; 3, 4- [36]; 5, 6, 9-12 - A. V. Korotkova; 7, 8- A. S. Brok-Volchansky

The undergrowth of deciduous $\mathrm{im}_{2}$ trees and conifers differs by adaptation to low light conditions under the forest canopy. For example, Picea abies and Pinus sylvestris undergrowth has an annual increment in height under the canopy compared to the growth in open space at the beginning of the $\mathrm{im}_{2}$ stage. However, needles on the shoots of the previous year fall off quickly due to a lack of light; the crown appears sparse. Growth in height at the end of the $\mathrm{im}_{2}$ stage is several times shorter than in individuals grown in open space (see Fig. 7, 2, 4). The order of branching increases in the crown as well as in individual shoots, and whole branches die. The growth of the shoots is mainly sympodial due to permanent dying off of the terminal bud. The maximum lifespan of $\mathrm{im}_{2}$ pine undergrowth under the canopy at the minimum light level is 22 years [37] and for spruce undergrowth 25 years [36]. 
An umbrella-shaped crown is formed in $\mathrm{im}_{2}$ undergrowth of most deciduous tree species under the forest canopy under the light minimum (see Fig. 7, 6, 12). This is because the growth of the shoots is reduced to a minimum, and the side branches are catching up to the height of the leader axis. An umbrella-shaped crown allows the plant to absorb low light from a larger area. The crown does not receive enough organic substances that are necessary to maintain its structure, and the crown begins to break under long-term growth in reduced light conditions; dead branches then appear. Such abruption of respiratory parts prolongs existence of the plant under the forest canopy. The undergrowth goes into a state of 'torchok' (Russian silvicultural term [88]). All aboveground parts of these individuals die off due to light deficiency (Fig. 8). The plant starts to tiller outward: dormant buds take over the growth on the surviving basal part of the stem [89-92]. Aboveground shoots appear to be dying every 15-25 years due to a lack of light. As a result, a system of numerous 'stumps' with adventitious roots is formed at the base of the plant. 'Stumps' contain reserves of dormant buds from which shoots form periodically short-lived juveniles and, then, immature shoots, which follow each other (see Fig. 8). The plants anticipate the appearance of gaps in the forest canopy in this state for further development. In the forest phytocoenology, 'torchki' are called quasi-senile individuals $(q s)$, because these plants are able to start developing again, reach the upper layer and become generative, when light conditions improve $[63,93]$. The biological meaning of the transition in the $q s$ state is exclusion of a significant share of perennial (respiring) parts. As a result, additional reserves of organic substances are necessary for the continued existence of phytocoenotic stress to appear in plants. For example, the maximum age of Acer campestre in the $\mathrm{im}_{2}$ stage under the forest canopy is only 24 years, and it increases to 52 years with the transition to the $q s$ state [76]. A. A. Chistyakova [83] noted that im undergrowth of Fagus sylvatica can remain viable in the $q s$ state for up to 70 years under a forest canopy with a lack of light.

Conducted in shady forests, a demographic study of tree populations showed that groups of $\mathrm{im}$ plants of Fagus sylvatica and Acer campestre contain up to $60-70 \%$ of $q s$ individuals, and groups of im plants of Carpinus betulus, Tilia cordata, Fraxinus excelsior and Ulmus glabra contain 5-20\%. Such a reduction in vitality ensures the survival of a substantial part of the undergrowth until the formation of gaps in the forest canopy [15, 92, 93].
Four groups of tree species are distinguished by features of formation of $q s$ individuals. The first group includes Fagus sylvatica, Acer campestre and A. platanoides. Their $q s$ undergrowth is formed in the darkest communities dominated by beech and hornbeam. The second group includes Fraxinus excelsior, Ulmus glabra, Tilia cordata, Sorbus aucuparia and Carpinus betulus. The qs plants of these species are more common in habitats with greater light allowances (e.g., under a canopy of oaks). The third group includes Quercus robur, Malus sylvestris, Acer tataricum, Betula pendula, Salix caprea and Populus tremula. Their $q s$ individuals are found only in the undergrowth of light communities - birch and pine forests - as well as at edges of broadleaved and coniferousbroadleaved forests. The fourth group is formed of Picea abies and Pinus sylvestris. Undergrowth of these species is not able to enter the qs state due to a lack of dormant buds at the base of stems [94].

Virginile plants (v). The main purpose of virginile undergrowth is rapid capture of gaps in the forest canopy that appear periodically on the death spots of old trees. Transition to this group is associated with the beginning of 'a period of great growth' in a tree's life, which is marked by foresters, physiologists and morphologists of plants. This period is characterised by a significant increase in height and significant development of the crown and trunk, as well as a rapid biomass accumulation speed $[33,61,74,95,96]$. Enhanced growth of the tree is provided physiologically: the intensity of leaf photosynthesis of species such as Quercus robur is doubled. Anatomy of the leaves changes during this time also. Single-layer palisade parenchyma of oak leaves is replaced by a two-layer system, and the spongy tissue becomes less friable $[97,98]$. These physiological and anatomical transformations are characteristic of adult-type leaves, which dominate in the crowns of $v$ trees and trees of subsequent ontogenetic states. Adult leaves differ by form of blades. For example, blades of Quercus robur become widely obovate with 6-8 pairs of lateral blades, Tilia cordata - roundlyovate and Alnus glutinosa - rounded with a notch at the top. Compound leaves of Fraxinus excelsior consist of 11-15 leaflets.

The $v$ individuals are shaped trees with a welldefined crown and trunk as a result of intensive growth. Unlike plants of the generative period, they are characterised by a smaller size and do not fruit. The $v$ individuals are divided into two subgroups according to the degree of development of their shoot and root systems. 


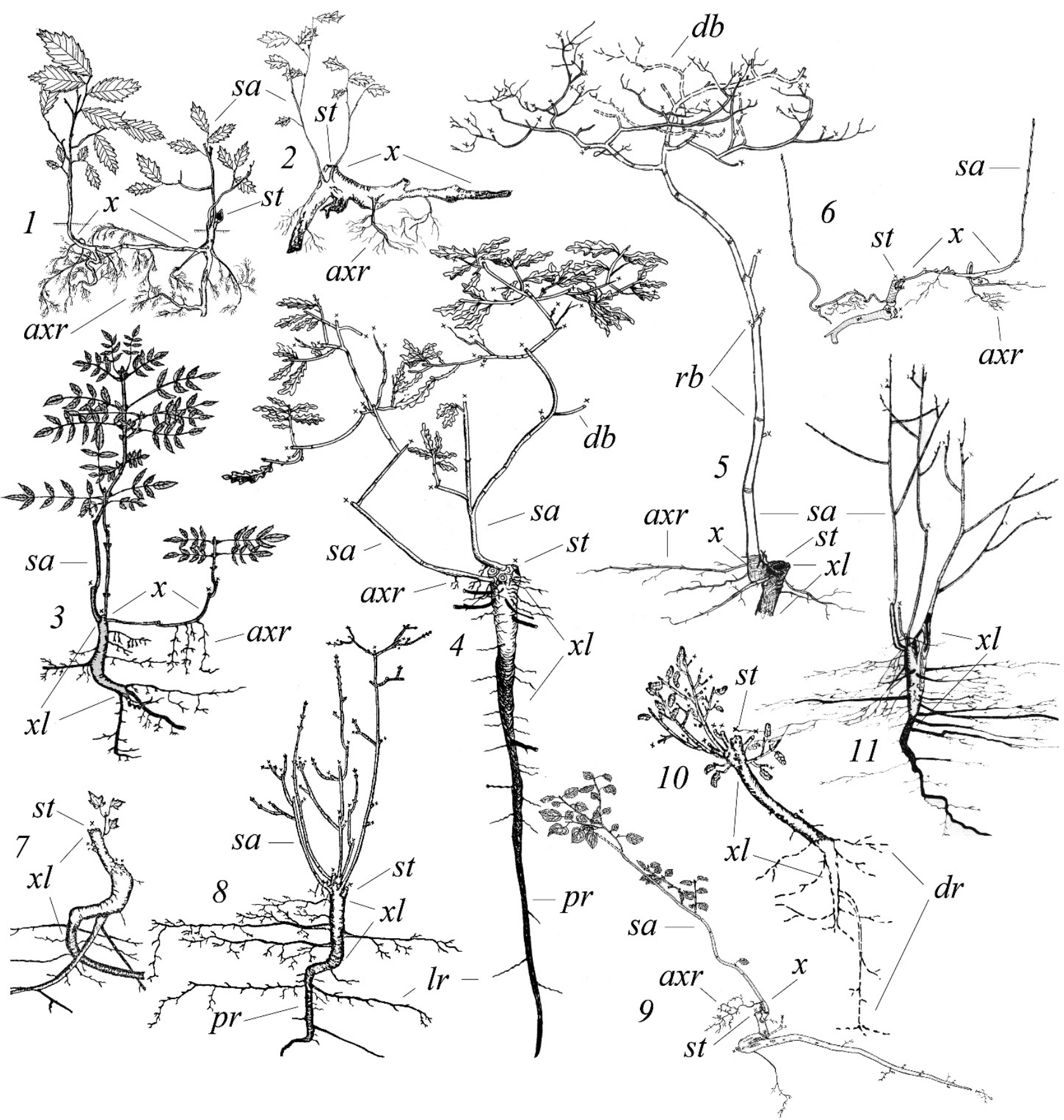

Fig. 8. Quasi-senile individuals:

1 - Ulmus glabra with thin xylorrhizoma (height $-40 \mathrm{~cm}$, ontogenetic stage $-\mathrm{im}_{1}$ ); 2 - U. glabra with thick xylorrhizoma (40 cm, im $)$; 3 - Fraxinus excelsior $\left(55 \mathrm{~cm}, \mathrm{im}_{1}\right) ; 4$ - Quercus robur $\left(65 \mathrm{~cm}, \mathrm{im}_{1}\right) ; 5-Q$. robur $(210 \mathrm{~cm}$, virginile plant of the first subgroup); 6 - Sorbus aucuparia $(20 \mathrm{~cm}, j) ; 7$ - Acer platanoides ( $8 \mathrm{~cm}, j)$; 8 - A. campestre (65 cm, im $)$; 9 - Malus sylvestris ( $\left.55 \mathrm{~cm}, \mathrm{im}_{1}\right) ; 10$ - Fagus sylvatica $\left(30 \mathrm{~cm}, \mathrm{im}_{1}\right)$; 11 - Tilia cordata $\left(60 \mathrm{~cm}, \mathrm{im}_{1}\right)$. Designations: $d b$ - dead branches, $d r$ - dead parts of the root system, sa - skeletal axis (aboveground shoot), st - 'stump' (basal part of dead aboveground shoot), $x I$-xylopodium. Other designations: see Figs. 2, 3, 6, 7. Sources and the authors of figures: 1, $2-[66]$; 3, 4, 7, 8, 10, 11 - [26, 33, 34, 93]; 5 - A. V. Korotkova; 6, 9 - A. C. Brok-Volchansky

Virginile plants of the first subgroup $\left(\mathrm{v}_{1}\right)$. Plants at edges and in glades and treefall gaps grow rapidly in height. The length of the annual increment for the major axis is $100 \mathrm{~cm}$ or more. Enhanced growth of the main axis and upper lateral shoots inhibits the development of the lower branches: their annual growth rates are 2-3 times less than that of the leader axis. Inhibition of development of the lower branches is not necessarily due to their shading, as this phenomenon is observed in sparse plantations with regular removal of weeds, where direct sunlight arrives freely at the lower branches. Ecologists and physiologists of woody plants suggest that this is due to the strong 
correlative inhibition of growth that is originating from the growing top of the main axis [61, 74]. The crown becomes narrow and conical due to such growth (Fig. 9, 1, 3, 6, 11, 13). The lower branches of the crown of most species touch the ground surface. Axes of the fifth order prevail in the shoot systems of intensive-branching plants (e.g., Acer campestre, Carpinus betulus and Quercus robur) and axes of the fourth order - at least in branching species (e.g., Acer platanoides, A. pseudoplatanoides and Fraxinus excelsior). Lateral shoots deviate from the trunk at an acute angle for most tree species (see Fig. 9, 1, 5, 6). The leaves in the crown are arranged into several layers. The effectiveness of the multi-layer crowns is higher at high densities of light. Many leaves are placed on long, annual shoots. Formation of a multi-layer crown is caused by the development of a powerful leader shoot. Over time, it becomes a trunk that carries the crown. Thus, the multi-layer crown extends vertically, and long annual increments with a large number of leaves occur - an evidence of active growth processes of the undergrowth.

Individuals that develop under a closed forest canopy in light deficiency usually have an umbrella-shaped crown (see Fig. 9, 8, 9, 12), where leaves are placed into a single layer. The effectiveness of such monolayer crowns is higher at low densities of light. Plants form long, horizontally placed shoots that form wider and thinner leaf blades. Self-shadowing of leaves is minimal. Annual increments of recent years are short: for example, annual increments of maple and ash are not more than $1 \mathrm{~cm}$ with only one pair of leaves. However, a higher order of branching is formed in the shoot system under a forest canopy compared to those at edges and in glades. Because of this, the number of shoots with leaves increases in the crown. All of this allows the use of diffuse light and sun glare from a larger area. From a detailed consideration of the crown, we can see a large number of traces from dying tops of shoots that are determined by lack of light and not by heredity. Stems of $v_{l}$ undergrowth are clear of the lower branches. This is because the top layer of leaves of umbrella-shaped crowns intercepts most of the scarce light, which is not enough to reach the lower branches, where respiration begins to prevail over photosynthesis and branches die (see Fig. 9, 8, 9). Other researchers have noted the benefits of an umbrella-shaped crown in light deficit conditions [72, 99]. In their view, a strong shading of undergrowth changes the distribution of assimilates: a smaller portion goes to the axial parts (e.g., stems and roots) and a large portion to leaf formation. This increases the adaptation of the organism to a lack of light. Thus, the umbrella-shaped crown, frequent replacement of the central apical shoot by lateral shoots, cleaning of the trunk from the lower branches and minimal annual increments are signs that the plant has reduced its growth processes and expects improved light conditions at a low level of vitality. In this state, $v_{l}$ individuals of oak can survive under the forest canopy up to 24 years, ash - up to 28 years, Norway maple - up to 37 years and spruce - up to 48 years [76]. Spruce undergrowth dies after the maximum age, but deciduous tree undergrowth passes usually into the qs state (see Fig. 8, 4, 5, 11) and continues to exist for many years under the oppression [93].

The tendency to form an umbrella-shaped crown is different for different tree species. Umbrella-shaped crown expression is not found in $v$ undergrowth of Pinus sylvestris, Populus tremula and Salix caprea. This is because their successful recovery is confined to sparse park forests as well as to large gaps in the forest canopy. Under these circumstances, solar energy is efficiently absorbed by the crown, which is extended in the vertical direction. For example, $v_{l}$ pine individuals form a fusiform crown, where sparse needles are located on several layers under shading (see Fig. 9, 2). Umbrella-shaped crowns of Betula pendula and Quercus robur are found only in light forests, but such crowns of Acer platanoides, A. campestre, Carpinus betulus, Fraxinus excelsior, Tilia cordata and Ulmus glabra are found in dark forests. The largest crown areas are formed by $v_{l}$ individuals of Ulmus glabra and Acer platanoides. The inability to create a broad umbrella-shaped crown, such as those of maple and elm, is a possible reason for a significant weakening of shade tolerance of Fraxinus excelsior in the $v$ state $[76,100]$.

An important factor in the normalisation of the photosynthetic activity of maturing undergrowth is the continuous improvement of lighting conditions, when old trees die. Observations of $v_{l}$ individuals of spruce and deciduous trees with an umbrellashaped crown have shown that with the formation of treefall gaps, the trees activate their growth and form a big trunk and a multilayer crown that extends in the vertical direction for $2-3$ years. The ecological significance of such reorganisation is rapid assimilation of free resources and rapid access to the upper layer for further development.

Virginile plants of the second subgroup $\left(v_{2}\right)$. Plants are fully formed and ready for fructification. The value of annual increment in height is greater than that of $v_{l}$ individuals at edges and in glades. The narrowly conical crown is pulled even more in the vertical direction (Fig. 10). Sixth-order axes predominate in the shoot systems of intensivebranching tree species, and the fifth-order axes predominate in less branching trees. The active 
growth of the main axis determines death of lower branches: the trunk is cleared of branches to a height of $2 \mathrm{~m}$ (see Fig. 10, 1, 9). Fracturing bark is formed by multiple initiations of new layers of periderm in increasingly deeper layers of bark and ap- pears in the basal part of the trunk of some individuals (see Fig. 10, 6, 7, 9). The age of $v_{2}$ individuals is relatively small - from 10-25 years in open space.
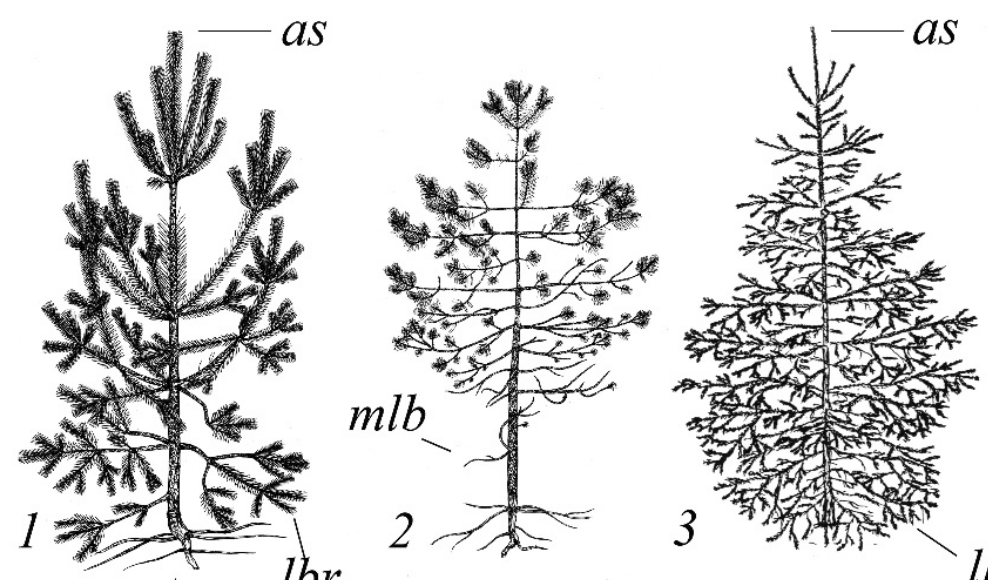

as
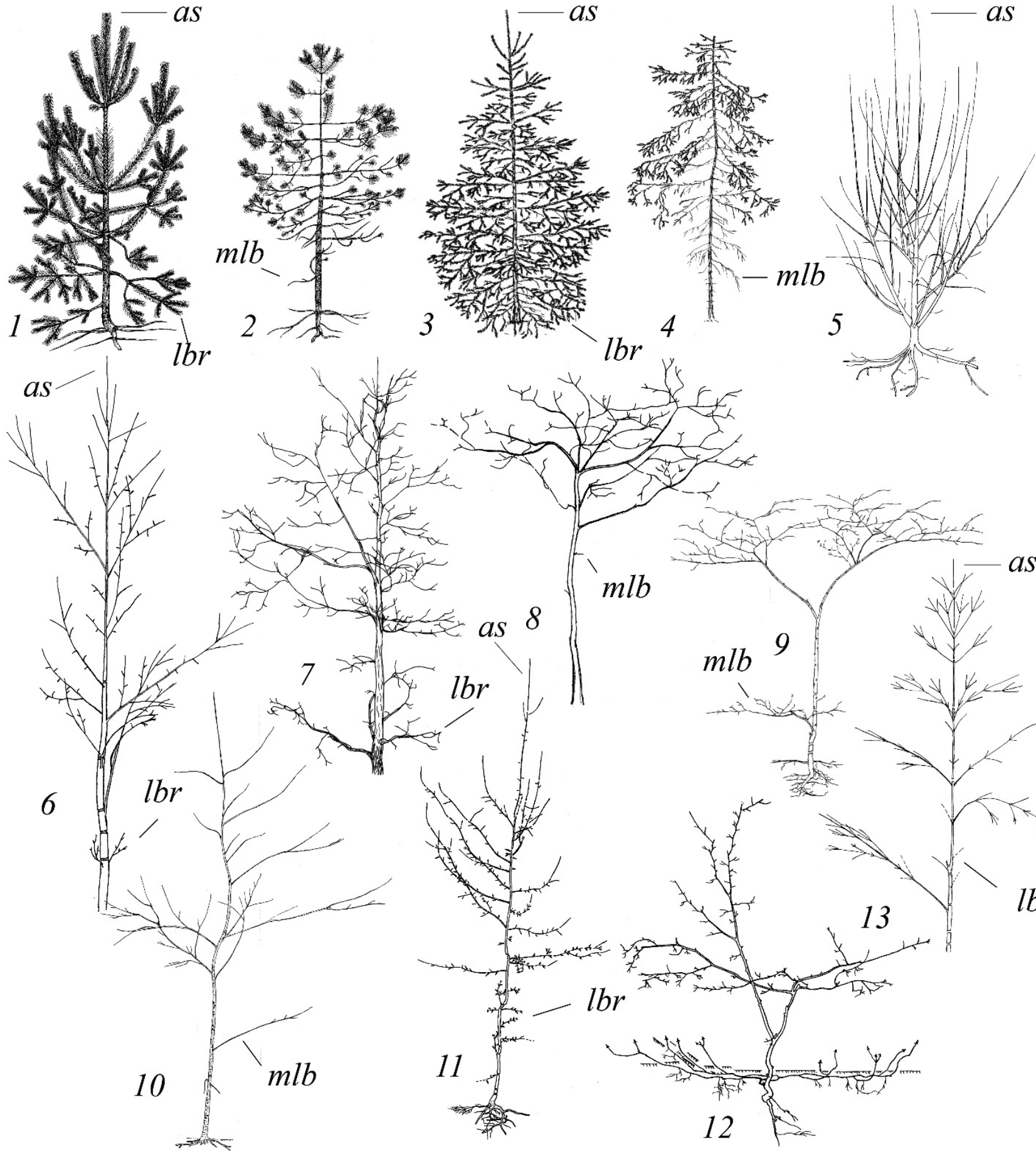

Fig. 9. Virginile plants of the first subgroup:

1, 2- Pinus sylvestris with normal (height - 2.0 m) and low (2.0 m) vitality; 3, 4 - Picea abies with normal (2.0 m) and low $(2.0 \mathrm{~m}$ ) vitality; 5 - Tilia cordata with normal vitality $(2.5 \mathrm{~m}) ; 6$ - Populus tremula with normal vitality $(7.0 \mathrm{~m})$;

7, 8 - Quercus robur with normal $(5.0 \mathrm{~m})$ and low $(4.0 \mathrm{~m})$ vitality; 9 - Ulmus glabra with low vitality $(4.2 \mathrm{~m})$; 10 - Alnus glutinosa with low v itality $(7.0 \mathrm{~m}) ; 11,12$ - Malus sylvestris with normal (6.0 m) and low (2.0 m) vitality; 13 - Acer platanoides with normal vitality $(6.0 \mathrm{~m})$. Designations: as - annual increment of shoot with increased growth, $\mathrm{lbr}$ - lower branches with inhibited growth, $\mathrm{mlb}$ - moribund and dying lower branches. Sources and the authors of figures: 1, 2 - N. A. Tatarenkova; 3, 4 - [36]; 5 - V. N. Korotkov; 6-9, 13 - A. V. Korotkova, 10 - K. V. Belyakov; 11,12 - A. S. Brok-Volchansky 

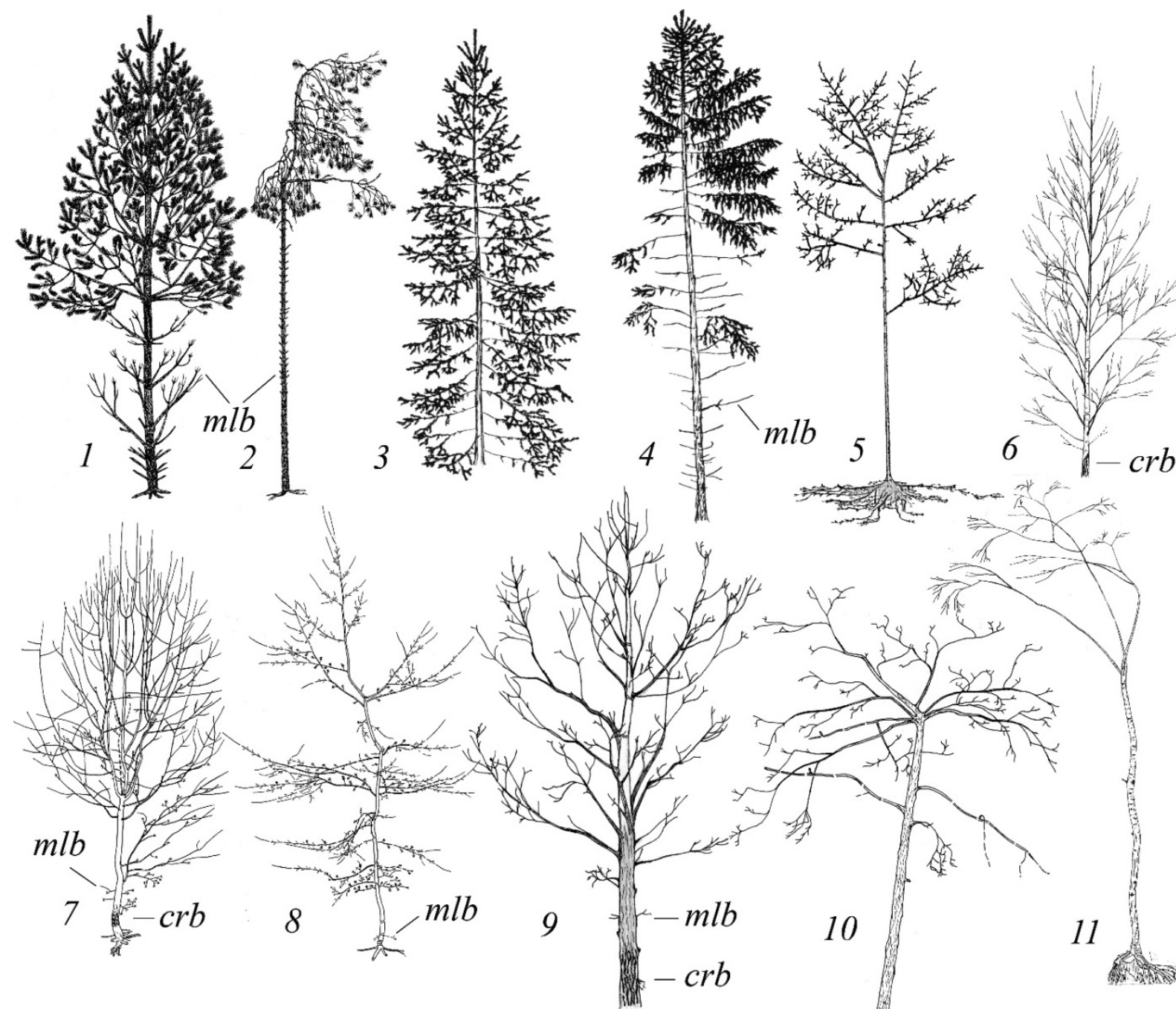

Fig. 10. Virginile plants of the second subgroup:

1, 2 - Pinus sylvestris with normal (height - $12 \mathrm{~m}$ ) and low (11 m) vitality; 3, 4-Picea abies with normal (12 m) and low (15 m) vitality; 5 - Tilia cordata with normal vitality (13 m); 6 - Betula pendula with normal vitality $(6 \mathrm{~m})$; 7, 8 - Malus sylvestris with normal (7 m) and low ( $8 \mathrm{~m}$ ) vitality; 9, 10 - Quercus robur with normal (11 $\mathrm{m}$ ) and low (12 $\mathrm{m}$ ) vitality; 11 - Alnus glutinosa with low vitality (13 m); Designation: crb - bark with cracks. Other designations: see Figs. 9, 10. Sources and the authors of figures: 1, 2 - N.A. Tatarenkova; 3, 4- [36]; 5 - [34];

$$
\text { 7, } 8 \text { - A.S. Brok-Volchansky; 6, 9, } 10 \text { - A.V. Korotkova; } 11 \text { - K.V. Belyakov }
$$

The ages of $v_{2}$ individuals formed in the forest are significantly more than those of individuals formed at edges and in glades: for example, the ages of Fagus sylvatica and Quercus robur are 60 years; Picea abies and Fraxinus excelsior 50 years; and Pinus sylvestris, Tilia cordata, Acer platanoides and A. campestre - 40 years $[19,33$, 36]. Such a delay of seed reproduction of younger trees is necessary to increase the height at which they can use additional lighting of the upper layers of the forest for development of generative organs. The $v_{2}$ plants, like those of previous ontogenetic stages, are able to reduce the energetic costs of maintaining respiring (non-photosynthetic) parts to prolong life under the forest canopy. The trunk is cleared from the lower branches at a considerable height (see Fig. 10, 2, 4, 5, 10, 11). Due to low light, these branches are ineffective; they do not contribute to the growth of the whole plant biomass. Researchers note that the balance of organic substances of the lower branches is negative under light deficiency; photosynthesis of leaves and needles cannot cover the costs of respiration [72]. As a result, the branches die. In this case, the multilayer crown is converted to a single-layer type, sometimes to umbrella-shaped (see Fig. 10, 10, 11). The branching order of shoot system increases. This crown captures effectively scattered light under the canopy. Often, small branches that do not work effectively die off in the crown. This is evident by a large number of replacements of the central apical shoot by lateral shoots in the shoot system. The $v_{2}$ individuals of pine and spruce do not form umbrella-shaped crowns under the canopy. Usually under a light deficit, the crown of pine spreads out and is one-sided, and the crown of spruce is one-sided and 
narrow-pyramidal (see Fig. 10, 2, 4). Trees occupy a place in the tree layer; the upper part of the crown is fully illuminated with the appearance of gaps. We know that more light for increasing photosynthesis and, thus, carbohydrate production stimulate formation of generative organs of trees [74].

Generative period. With access to the tree layer, generative trees direct major efforts to keep positions in the community (i.e., for assimilation of the largest possible amount of resources and for reduction of their availability to other organisms). Another important task of generative individuals is to produce seed for the population. In this regard, all morphological and physiological changes in the generative period are directed at solving these problems. Three ontogenetic stages are allocated within this period: young, mature and old generative.
Young generative plants $\left(g_{1}\right)$. The appearance of generative organs is a distinctive feature of this ontogenetic stage. The fruits of flowering trees and seed cones of gymnosperms are concentrated usually in the upper half of the crown [26, 33]. Vegetative growth of $g_{l}$ trees is greatest at edges and in glades: plant height during this ontogenetic stage increases 3-4 times. Growth in height is characterised by maximum values: in some individuals of Pinus sylvestris and Quercus robur $-80 \mathrm{~cm}$; Picea abies and Acer platanoides $-90 \mathrm{~cm}$; Betula pendula $-120 \mathrm{~cm}$; and Ulmus glabra and Alnus glutino$s a-130 \mathrm{~cm}$. Growth of lateral branches is enhanced together with strong growth of the leader axis. As a result, the narrowly pyramidal crown is replaced by a wide pyramidal one in some individuals in the $g_{l}$ stage (Fig. 11).
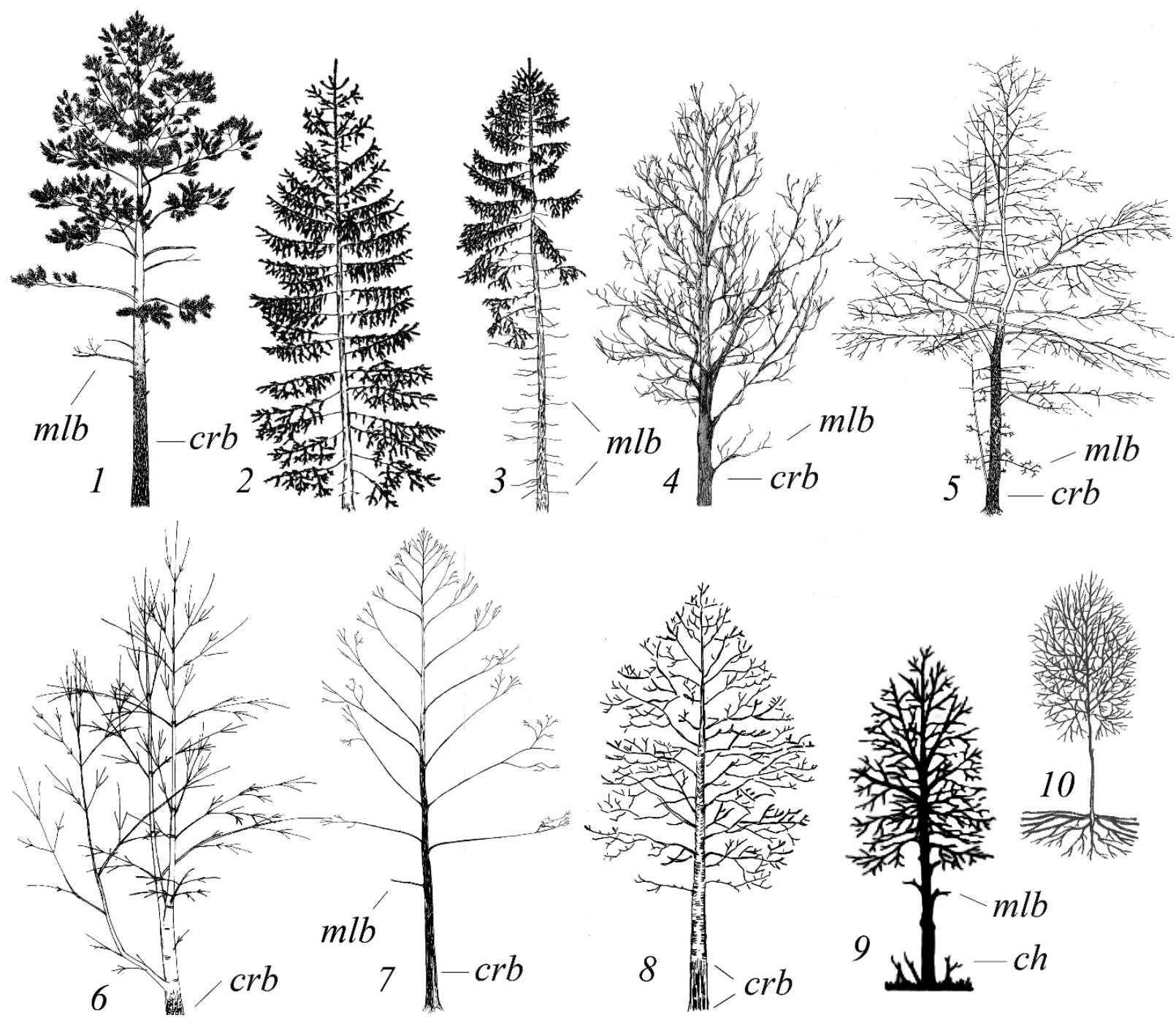

Fig. 11. Young generative plants:

1 - Pinus sylvestris with normal vitality (height - $15 \mathrm{~m}) ; 2,3$ - Picea abies with normal (14 m) and low (17 m) vitality; 4 - Quercus robur with normal vitality (13 m); 5 - Malus sylvestris with normal vitality (12 m); 6 - Acer campestre with normal vitality (9 m); 7-Alnus glutinosa with normal vitality $(16 \mathrm{~m}) ; 8$ - Populus tremula with normal vitality (13 $\mathrm{m})$; 9 - Tilia cordata with normal vitality $(14 \mathrm{~m}) ; 10$ - Salix caprea with normal vitality $(7 \mathrm{~m})$. Designations: ch - coppice shoots at the base of the trunk. Other designations: see Figs. 9, 10. Sources and the authors of figures: 1 - N. A. Tatarenkova; 2, 3- [36]; 4, 6-A. V. Korotkova; 5-A. S. Brok-Volchansky; 7 - K. V. Belyakov; 8 - O. I. Evstigneev; 9 - A. I. Shirokov; $10-[32]$ 
The prevailing order of branching in the shoot system for intensively branching trees is the seventh and for less branching trees - the sixth. As in $v$ individuals, the main axis heightens the crown and is traced from the bottom to the top. The crown is raised above the ground to a height from 1-10 $\mathrm{m}$. The bark with wide, deep cracks is formed in the basal part of the stem for all tree species: for example, the bark length of Acer campestre is $0.3 \mathrm{~m}$ and Pinus sylvestris $-3.0 \mathrm{~m}$ (see Fig. 11).

Most of the trees are characterised by subnormal and low (sub-lethal) vitality under forest conditions. Plants with sub-normal vitality grow slowly in height and have small crowns, but their stems are thicker. Trees with low vitality are stagheaded, have minimum increments of the main axis and have relatively large trunk diameters.

Betula pendula can produce seed in 6 years; Carpinus betulus, Acer platanoides and Pinus sylvestris - 11 years; Picea abies and Quercus robur 13 years; and Ulmus glabra and Tilia cordata 16 years in an open space (Table 2). Youthful fer- tility occurs in trees. In the Kanev Nature Reserve (Ukraine), some 7-year-old oak individuals that have developed in the meadows and resemble $\mathrm{im}_{2}$ undergrowth can form a single acorn. Some small Pinus sylvestris individuals (that resemble $\mathrm{im}_{1}$ undergrowth) form male cones (e.g., microstrobilus or pollen cone) and even female cones (e.g., megastrobilus or seed cone) under free growth on poor, sandy soils in the Kostomuksha Nature Reserve (Republic of Karelia). Researchers observed early fruiting of Quercus robur (5 years) near Volgograd [61]. Physiologists argue that premature formation of generative organs under good light conditions is often associated with nitrogen deficiency. Excess light and a lack of nitrogen induce the formation of reproductive organs for young trees, but good nitrogen ensures stimulation of vegetative growth and inhibits seed production [74]. Trees are required for many decades to undergo vegetative growth before the first appearance of generative organs in a forest environment (Table 2).

Table 2

Some seed bearing characteristics of trees (by [76], with additions)

\begin{tabular}{|c|c|c|c|c|c|}
\hline \multirow{2}{*}{ Tree species } & \multicolumn{3}{|c|}{ Beginning of seed production, years } & \multicolumn{3}{|c|}{ Potential seed productivity, number of ovules per one tree } \\
\cline { 2 - 6 } & \multirow{2}{*}{ in forest } & \multirow{2}{*}{ glades, forest edges } & \multicolumn{2}{|c|}{$g_{1}$} & $g_{2}$ \\
\cline { 3 - 6 } & & & in first year of seed bearing & in 20 years & in 40-50 years \\
\hline Betula pendula & 25 & 6 & 17000 & 11352000 & 90000000 \\
\hline Salix caprea & 15 & 4 & 5000 & 15580000 & 38700000 \\
\hline Populus tremula & 25 & 8 & 12000 & - & 23500000 \\
\hline Carpinus betulus & 30 & 11 & 12000 & 31000 & 500000 \\
\hline Tilia cordata & 40 & 16 & - & - & 583000 \\
\hline Acer campestre & 40 & 12 & 60 & 25000 & 832000 \\
\hline Ulmus glabra & 30 & 16 & 4700 & 165000 & 4965000 \\
\hline Picea abies & 50 & 13 & 450 & 16000 & 1537000 \\
\hline Quercus robur & 60 & 13 & 140 & - & 112000 \\
\hline Acer platanoides & 40 & 11 & 400 & - & 466000 \\
\hline Fraxinus excelsior & 45 & 12 & 390 & - & 170000 \\
\hline Pinus sylvestris & 40 & 11 & 300 & 15000 & 1346000 \\
\hline Malus sylvestris & 20 & 10 & 120 & 18000 & 971000 \\
\hline Acer tataricum & 30 & 10 & 620 & - & 4566000 \\
\hline
\end{tabular}

Mature generative plants $\left(\mathrm{g}_{2}\right)$. A domed crown is a distinctive feature of most mature generative trees ( $g_{2}$ stage) (Fig. 12). This is due to weakening of the growth of the main axis: its annual growth is comparable to the increments of the lateral branches. G. Zeding [101] believes that not only does the main apical shoot impact inhibition of the lateral shoots, but also that the lateral shoots hinder the development of the apical shoot. As a result, a pyramidal and peaked crown is transformed gradually into a domed crown under the influence of summary suppression by a growing number of lateral branches. As a result, the main axis at the top is lost. The change in shape of the crown coincides with withering away of weaker and thinner branches of its inner part; only strong branches are saved. The system of shoots changes to sympodial for monopodially growing trees in the $g_{2}$ stage. The prevailing order of branching in the crown of intensive-branching trees is the eighth and for less branching trees - the seventh. Weakening of the main axis growth is accompanied by an overall inhibition of growth processes; tree height increases slightly during this stage. The bark with deep cracks in different tree species expands to a height equal to up to two-thirds of the stem height.

Individuals with sub-normal and low vitality occur frequently in the forest environment. Subnormal-vitality trees have a small diameter of the crown; dead branches are usually in the lower part of crown (see Fig. 12, 4, 9). The diameter of the trunk is the same or slightly larger than the diameter of normal-vitality trees. At times, large scars are vis- 
ible on the trunk as a result of many replacements of the central apical shoot by lateral shoots in the past. Low-vitality trees differ from sub-normal-vitality trees by a smaller trunk diameter.

Seed production of $g_{2}$ individuals is the maximum. Usually, seeds are dispersed throughout the crown. It is possible to rate tree fertility to determine potential seed production (i.e., the number of ovules that produces one individual during the growing season). This criterion is less dependent on external conditions in contrast to actual seed production [102].
Tilia cordata in the $g_{1}$ stage forms only 18 thousand ovules, Acer campestre - 25 thousand, Carpinus betulus - 31 thousand, Ulmus glabra - 165 thousand and Betula pendula - 11 million ovules, but trees in the $g_{2}$ stage form one or two orders of magnitude greater numbers of ovules (Table 2). The actual seed productivity of $g_{2}$ trees is much smaller: for example, Tilia cordata in a forest community forms only a few thousand nuts [26], and Acer campestre forms only two thousand samaras [27].

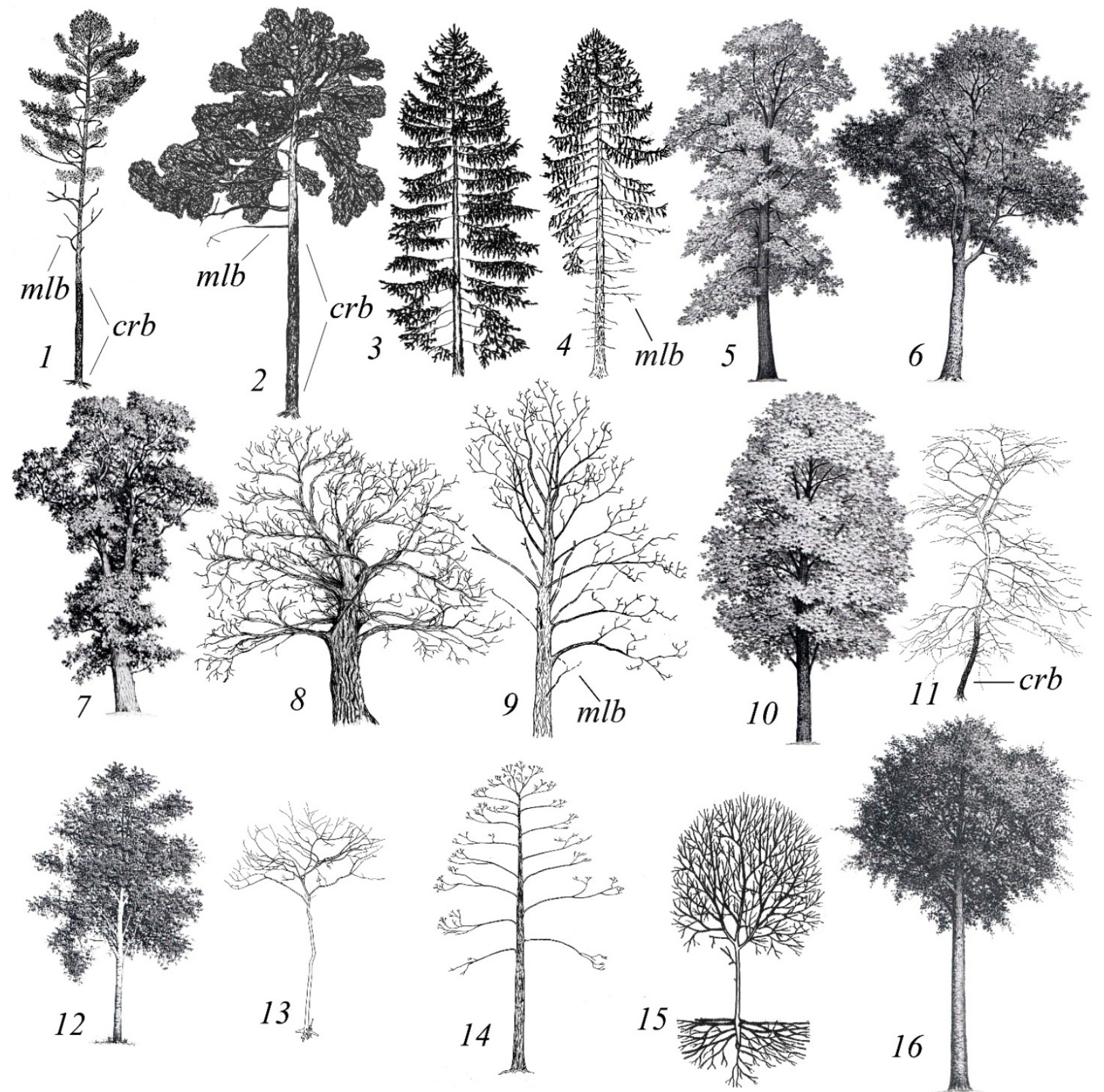

Fig. 12. Mature generative plants:

1, 2 - Pinus sylvestris with normal vitality in the beginning (height $-20 \mathrm{~m}$ ) and in the middle $(24 \mathrm{~m})$ of the ontogenetic stage; 3, 4- Picea abies with normal (19 m) and low (20 m) vitality; 5 - Tilia cordata with normal vitality (23 m); 6 - Fraxinus excelsior with normal vitality (22 m); 7 - Ulmus laevis with normal vitality (23 m);

8, 9 - Quercus robur with normal (19 m) and low (22 m) vitality; 10 - Acer platanoides with normal vitality ( $23 \mathrm{~m})$; 11 - Malus sylvestris with normal vitality (16 m); 12, 13 - Sorbus aucuparia with normal (15 m) and low (12 m) vitality;

14 - Alnus glutinosa with normal vitality (22 m); 15 - Salix caprea with normal vitality (12 m); 16 - Fagus sylvatica with normal vitality (24 m). Designations: see Figs. 9, 10. Sources and the authors of figures: 1 - N. A. Tatarenkova; 2, 8, 9 - A. V. Korotkova; 3, 4 - [36]; 5-7, 10, 12, 16 - [103, 104]; 11, 13 - A. S. Brok-Volchansky; 14 - K. V. Belyakov; 15 - [32] 
Mass seed production is reflected in the development of the vegetative sphere of trees: increments of trunk thickness are usually reduced 1.5-2 times a year from abundant seed production and thereafter [74]. Therefore, trees experience generous seed production only intermittently. Analysis of the literature has shown that the share of bad harvest years in the generative period of Quercus robur, Picea abies and Fagus sylvatica accounts for $65-72 \%$ of the time; of Fraxinus excelsior, Pinus sylvestris, Carpinus betulus and Acer platanoides - 35-50 \%; and Sorbus aucuparia, A. campestre and A. tataricum - 13-26\%. Years with poor harvests are rare for Tilia cordata, Betula spp., Populus tremula, Salix caprea and Alnus spp. [94]. In years of poor seed production, the main flow of organic substances is directed to the development of vegetative organs, which enhances the competitive power of trees.
Old generative plants $\left(g_{3}\right)$. The crown is usually domed at the beginning of the $g_{3}$ stage (Fig. 13, 2, 5-7). However, it becomes flat-topped in the middle and at the end of the stage (Fig. 13, $1,3,4,8)$. This is because growth in height of trees stops, and the upper part of the trunk dries out and dies. Dead skeletal branches appear in the crown. The prevailing branching order of intensive branching trees is the ninth and of less branching the eighth. The height of the trees of normal vitality is maximal: Fraxinus excelsior and Picea abies - up to $60 \mathrm{~m}$; Quercus robur, Fagus sylvatica and Pinus sylvestris - up to $50 \mathrm{~m}$; Acer platanoides, Populus tremula, Tilia cordata and Ulmus glabra - up to $40 \mathrm{~m}$; and A. campestre and Betula pubescens Ehrh. - 25 m [105, 106]. Usually, the bark with deep cracks is expressed all over the trunk in old trees.
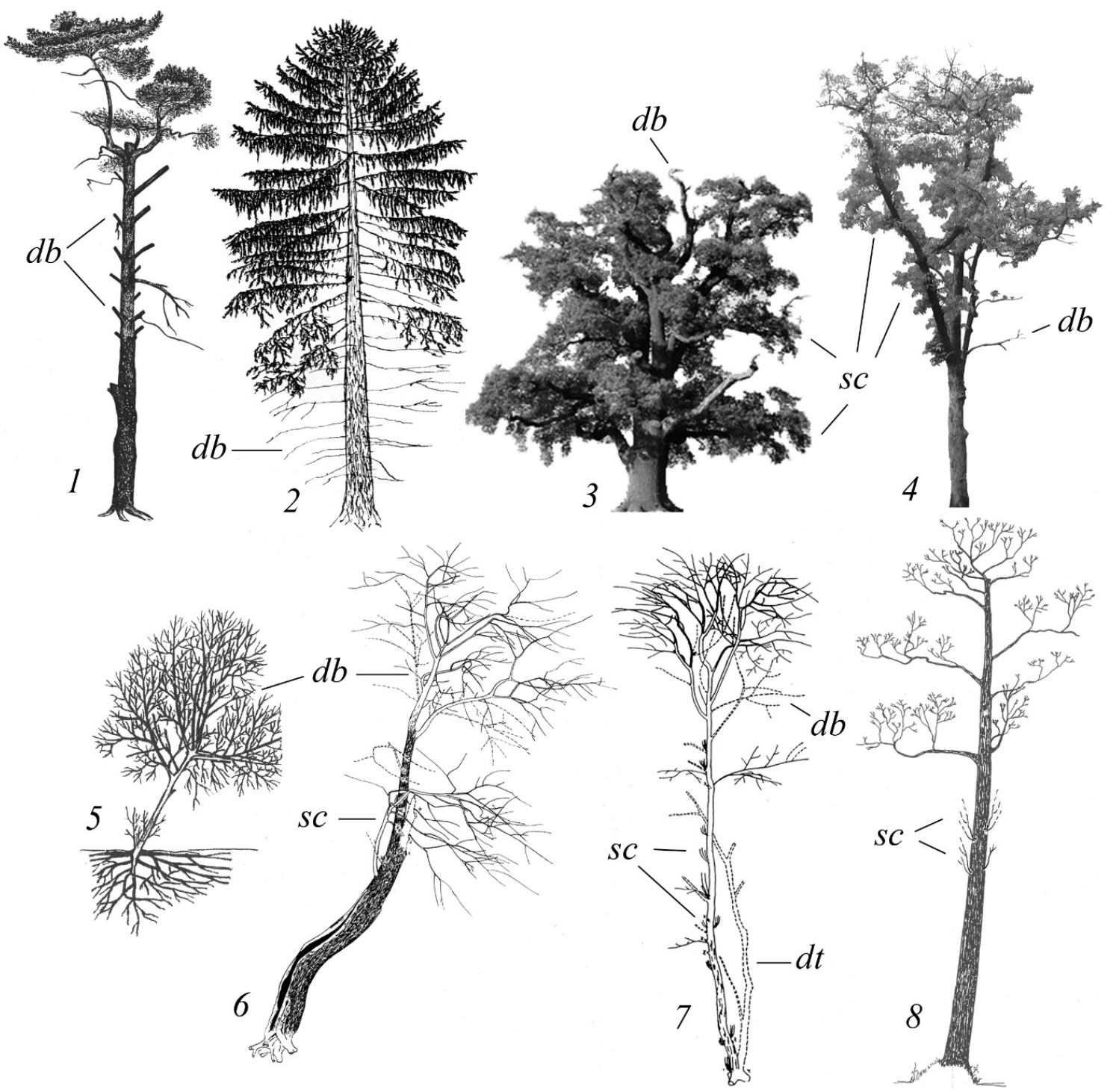

Fig. 13. Old generative trees with normal vitality:

1 - Pinus sylvestris (height - 23 m); 2 - Picea abies (23 m); 3 - Quercus robur (21 m); 4 - Fraxinus excelsior grown in the forest (24 m); 5 - Salix caprea (12 m); 6 - Malus sylvestris (18 m); 7 - Sorbus aucuparia (15 m);

8 - Alnus glutinosa (23 m). Designations: sc - secondary crown, $d b$ - dead branches, $d t$ - dead trunk. Sources and the authors of figures: 1 - N. A. Tatarenkova; $2-[36] ; 3,4-0$. I. Evstigneev; $5-$ [32];

6, 7- A. S. Brok-Volchansky; 8 - K. V. Belyakov 
The height of the sub-normal-vitality trees is smaller. The trunk is often larger in diameter than those of individuals of normal vitality. The surface of the trunk is covered with large scars. These trees may be affected by piped rot. Low-vitality trees have all the features listed above, but they have much smaller trunk diameters.

Works of physiologists have shown that one of the causes of aging and death of a tree is due to an increased proportion of the total biomass of perennial respiring parts (i.e., trunks, shoots, roots) with age and a reduced proportion of leaves, creating an organic matter for respiration [107-109]. As a result, the time in the tree's life comes when the assimilate balance approaches zero or becomes negative. In other words, all the organic substances produced during photosynthesis are spent on respiration completely. At the same time, growth processes are slowed down and stopped. The plant becomes exhausted and dies, but death does not occur immediately. There is a life extension mechanism of trees. It is manifested in rejection of inefficient respiring parts (i.e., old skeletal boughs and large branches), where almost all the organic substances, produced during photosynthesis, are spent on respiration, and nothing remains for export. The crown becomes sparse and light allowance within increases, when boughs and branches die off. Researchers $[78,110]$ believe that improved illumination is one of the causes of awakening of dormant buds on the trunk and branches and formation of a secondary crown.

Among trees, a secondary crown is not formed in Pinus sylvestris. Studying oaks, I. V. Turkevich [111] wrote that the area of individual leaves of the secondary crown is more than five times the leaf area of the primary crown; its leaves are thinner and contain more chlorophyll. It allows the plant to use the scattered light inside the crown efficiently. As a result, the assimilating surface increases again, and the positive balance of organic substances in plants is formed, which is necessary to sustain life of aging trees. V. A. Kazarian [112] argued that dieback, death of the skeletal branches and formation of the secondary crown temporarily restore the root-leaf connection, impaired with age, and contribute to rejuvenation of some old trees.

Through this mechanism of extending life, the age limit of Betula pubescens in free growth may reach 150 years; Acer campestre - 200 years; Betula pendula and Populus tremula - 250 years; Alnus glutinosa and Ulmus glabra - 300 years; Acer platanoides - 500 years; Fraxinus excelsior and Pinus sylvestris - 600 years; Tilia cordata 815 years; Fagus sylvatica - 930 years; Picea abies -
1200 years; and Quercus robur - more than 2000 years within the zone of coniferous-deciduous forests of Eastern Europe [1,74]. This age limit is deduced for individuals that grew up free of others. Tree life is shorter in the forest community. For example, the greatest age for Betula pendula and Populus tremula is only 100 years; Alnus glutinosa, Fraxinus excelsior and Tilia cordata - 110 years; Acer platanoides - 130 years; Picea abies 150 years; Pinus sylvestris - 160 years; and Quercus robur - 180 years in the strict 'Bryansk Forest' nature reserve (Bryansk region). This is because rising trees shade the lower leaves of adult trees in the forest and weaken the photosynthetic activity of the adult trees. Unfavourable balance of photosynthesis and respiration of the lower and middle branches as well as of the entire body defines early aging of trees in a forest community. Aspen and birch grow old particularly rapidly. It is known that these species have a relatively lower lability of their photosynthetic light curve $[68,113]$, and shadow leaves are absent in their crowns [72]. In addition, the relatively low age of the trees is determined now by a short rotation of felling in the exploited forests, and trees rarely live until their natural death.

Post-generative period. Most trees, affected by disease, die usually in the $g_{3}$ stage. Only single individuals of trees advance to the post-generative period during ontogeny. This period is represented by only one ontogenetic stage. It covers the time during which a tree loses the ability to form generative organs until its death.

Senile trees (s). Senile individuals are extreme manifestations of aging in trees. They are characterised by extreme decrepitude. The primary crown dies fully in senile trees. The top of the tree is dry or broken (Fig. 14). Only a secondary crown is saved, which is formed from dormant buds mostly on the middle and lower parts of the trunk. Leaves of juvenile or sub-adult type are formed on tree's shoots. Live wood is stored only on the periphery of the trunk; the bark is peeled off sometimes. Generative organs are not formed. Light, temperature and other regimes are gradually changing under the canopy of senile trees as their crowns are thinning. Therefore, the younger generation of trees can adapt gradually to new conditions for 5-50 years, which corresponds to the duration of the stage of senile trees [33].

\section{Conclusion}

During the development of all tree species, uniform ontogenetic stages are allocated, which are characterised by the morphological similarity. 
A distinctive feature of seedlings is cotyledons, of juvenile plants - one elongated shoot that may consist of several annual increments and of immature plants - appearance of lateral elongated shoots. As a rule, virginile and young generative trees are distinguished by a conical crown form, and their main ax- is is traced from the bottom up to the top. A domeshaped crown is typical for mature generative individuals of most tree species, while a flat-topped crown with dead branches is typical for old generative trees. The primary crown dies completely, and only a secondary crown remains in senile trees.

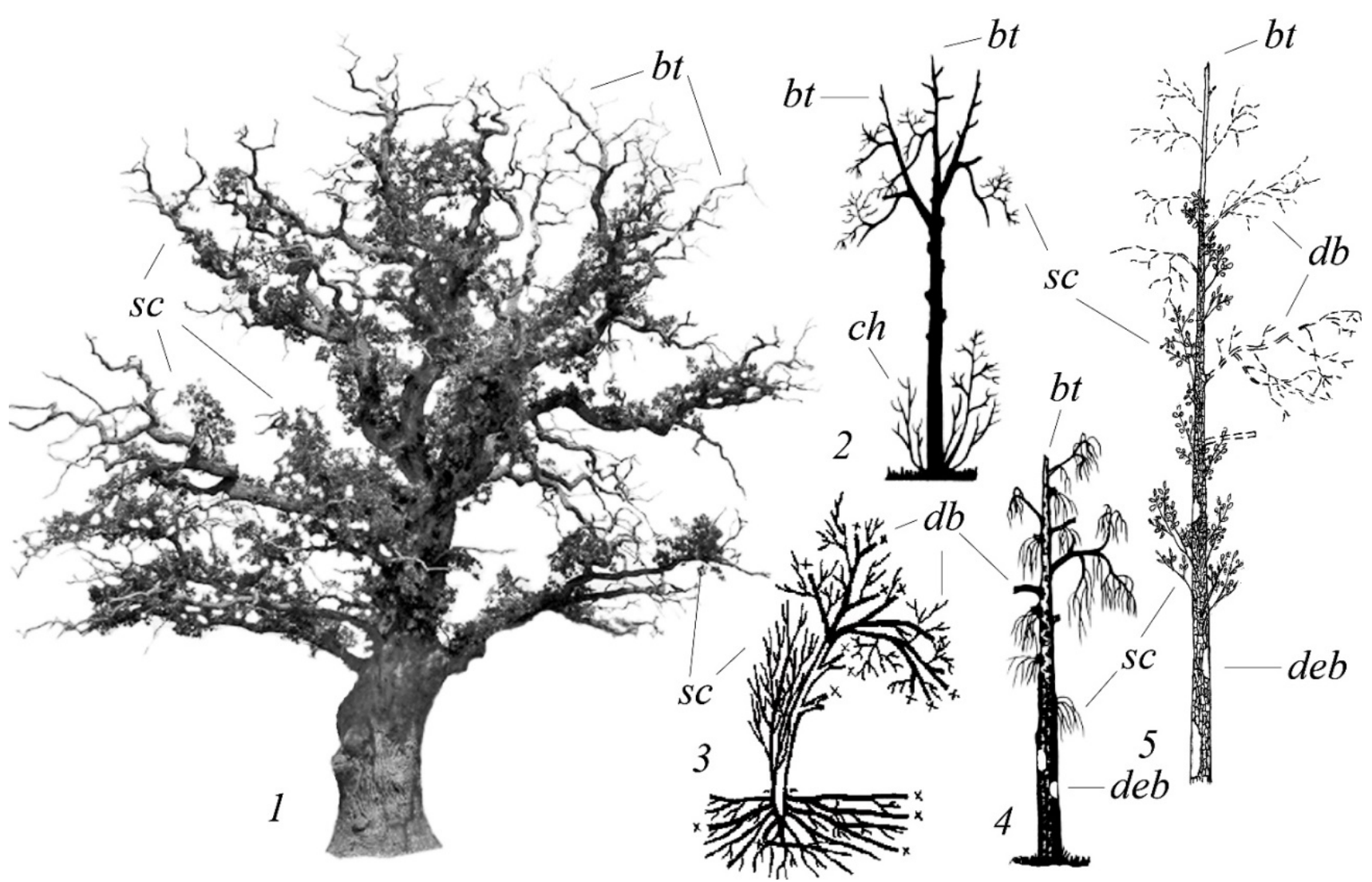

Fig. 14. Senile plants:

1 - Quercus robur with normal vitality grown in meadow (height - $20 \mathrm{~m}$ ); 2 - Tilia cordata with normal vitality grown in forest (19 m); 3- Salix caprea with normal vitality grown at forest edge (10 m); 4 - Betula pendula with normal

vitality grown in open area (19 $\mathrm{m}) ; 5$ - Alnus glutinosa with low vitality grown in forest (18 m). Designations: bt - broken top, deb - delamination of bark. Other designations: see Fig. 11, 13. Sources and the authors of figures: 1- O. I. Evstigneev; 2, 4 - A. I. Shirikov; 3- [32]; 5-A. V. Korotkova

A variety of living conditions in forest communities determines morphological variations of individuals in different ontogenetic stages and is reflected in their level of vitality. Some individuals are powerfully developed in terms of overall ontogeny. Others are at an average level, while others are so deprived that they cannot advance through all stages of individual development.

Plants belonging to the first level are characterised by a normal life: development occurs without long delays during the pre-generative period; trees have for the given ontogenetic state a maximum annual increment and general proportions (height, crown diameter and stem); and the shoot system is formed from buds of regular renewal.

Plants that are in the second or sub-normal level of vitality stay longer in the pre-generative period. They have smaller trunks and crowns as well as annual increments in height. An umbrella-shaped crown is typical for undergrowth. Not only buds of regular renewal, but dormant buds of the basal parts of annual shoots may be involved in formation of the trunk. The leader axis increases sympodially, regardless of genetic rules that govern growth.

Plants that are in the third (sub-lethal) level of vitality are characterised by the greatest developmental delay, minimum annual increment and prevalence of dead branches in the crown. Most sub-lethal individuals die without passing through all the stages of ontogeny. However, as long as the processes of dying off do not affect significantly the root and shoot systems, sub-lethal undergrowth is able to advance to the generative state with improved lighting conditions and pass through all the stages of ontogeny. 


\section{References}

1. Корчагин, А. А. Определение возраста деревьев умеренных широт / А. А. Корчагин // Полевая геоботаника. - М. ; Л. : АН СССР, 1960. - Т. 2. - С. 209-240.

2. Harper, J. L. Population biology of plants / J. L. Harper. - London ; New York : Academic Press, 1977. - 892 p.

3. Silvertown J. W. Introduction to plant ecology / J. W. Silvertown. - London ; New York : Longman, 1982. 209 p.

4. Работнов, Т. А. Жизненный цикл многолетних травянистых растений в луговых ценозах / Т. А. Работнов // Геоботаника. - М. ; Л. : АН СССР, 1960. - Т. 6. - С. 7-204.

5. Онтогенез и возрастной состав популяций цветковых растений / под ред. А. А. Уранова. - М. : Наука, 1967. $-156 \mathrm{c}$.

6. Вопросы морфогенеза цветковых растений и строения их популяций / под ред. А. А. Уранова. - М. : Наука, 1968. - $233 \mathrm{c}$.

7. Уранов, А. А. Возрастной спектр фитоценопопуляции как функция времени и энергетических волновых процессов / А. А. Уранов // Биологические науки. - 1989. - № 11. - С. 7-34.

8. Age states of plants of various growth forms : a review / L. E. Gatzuk, O. V. Smirnova, L. I. Vorontzova, L. B. Zaugolnova, L. A. Zhukova // Journal of Ecology. - 1980. - Vol. 68 (3). - P. 675-696.

9. Shorina, N. I. The population biology of ephemeroides / N. I. Shorina, O. V. Smirnova // Handbook of vegetation science. Part III. The population structure of vegetation / ed. J. White. - Dordrecht : Dr. W. Junk Publishers, 1985. P. 225-240.

10. Ценопопуляции растений (основные понятия и структура). - М. : Наука, 1976. - 217 с.

11. Заугольнова, Л. Б. Ценопопуляции растений (очерки популяционной биологии) / Л. Б. Заугольнова, Л. А. Жукова, А. С. Комаров, О. В. Смирнова. - М. : Наука, 1988. - 184 с.

12. Smirnova, O. V. Ontogeny of different life forms of plants and specific features of age and spatial structure of their populations / O. V. Smirnova, M. M. Palenova, A. S. Komarov // Russian Journal of Developmental Biology. - 2002. Vol. 33 (1). - P. 1-10 [Translated from Ontogenez. - 2002. - Vol. 33 (1). - P. 5-15].

13. Заугольнова, Л. Б. О биологии самосева обыкновенного ясеня (Fraxinus excelsior L.) / Л. Б. Заугольнова // Биологические науки. - 1967. - № 5. - С. 98-102.

14. Заугольнова, Л. Б. Возрастные этапы в онтогенезе ясеня обыкновенного (Fraxinus excelsior L.) / Л. Б. Заугольнова // Вопросы морфогенеза цветковых растений и строения их популяций. - М. : Наука, 1968. C. 81-102.

15. Смирнова, О. В. Популяционная организация буковых лесов Закарпатья / О. В. Смирнова, А. А. Чистякова, С. И. Рипа, Н. И. Лысых // Бюллетень МОИП. Отдел биологический. - 1989. - Т. 94 (5). - С. $78-91$.

16. Евстигнеев, О. И. Популяционная организация грабовых лесов Каневского заповедника / О. И. Евстигнеев, В. Н. Коротков, Л. В. Бакалына // Бюллетень МОИП. Отдел биологический. - 1992. - Т. 97 (2). - С. 81-89.

17. Евстигнеев, О. И. Зоохория и дальность разноса семян в хвойно-широколиственных лесах Восточной Европы / О. И. Евстигнеев, П. В. Воеводин, В. Н. Коротков, И. А. Мурашев // Успехи современной биологии. 2013. - T. 133 (4). - С. 392-400.

18. Восточноевропейские широколиственные леса / под ред. О. В. Смирновой. - М. : Наука, 1994. - 364 с.

19. Восточноевропейские леса: история в голоцене и современность / под ред. О. В. Смирновой. - М. : Наука, 2004. - Кн. 1. - 479 с.

20. Восточноевропейские леса: история в голоцене и современность / под ред. О. В. Смирновой. - М. : Наука, 2004. - Кн. 2. -575 c.

21. Браславская Т. Ю. Возобновительные процессы в популяциях широколиственных видов деревьев, обитающих в лесистых пойменныхландшафтах Европейской России / Т. Ю. Браславская // Известия Самарского НЦ РАН. - 2013. - Т. 15 (3). - C. 1041-1045.

22. Bernacci, L. C. Estrutura de estádios ontogenéticos em população nativa da palmeira Syagrus romanzoffiana (Cham.) Glassman (Arecaceae) / L. C. Bernacci, F. R. Martins, F. F. Maës dos Santos // Acta Botanica Brasilica. 2008. - Vol. 22 (1). - P. 119-130.

23. Silveira, A. S. Are tree ontogenetic structure and allometric relationship independent of vegetation formation type? A case study with Cordia oncocalyx in the Brazilian Caatinga / A. S. Silveira, F. R. Martins, F. S. Araújo // Acta Oecologica. - 2012. - Vol. 43. - P. 126-133.

24. Rosseto, V. Ontogeny, allometry and architecture of Psychotria tenuinervis (Rubiaceae) / V. Rosseto, M. S. Carneiro, F. N. Ramos, F. F. Maes dos Santos // Acta Botanica Brasilica. - 2013. - Vol. 27 (4). - P. 730-736.

25. Нухимовский, Ю. Д. Онтогенез пихты сибирской в условиях Подмосковья / Ю. Д. Нухимовский // Бюллетень МОИП. Отдел биологический. - 1971. - Т. 76 (2). - С. 105-112.

26. Чистякова А. А. Большой жизненный цикл Tilia cordata Mill. / А. А. Чистякова // Бюллетень МОИП. Отдел биологический. - 1979. - Т. 84 (1). - С. 85-98.

27. Полтинкина, И. В. Онтогенез, численность и возрастной состав ценопопуляций клена полевого в широколиственных лесах Европейской части СССР / И. В. Полтинкина // Бюллетень МОИП. Отдел биологический. - 1985. - Т. 90 (2). - С. 79-88.

28. Махатков, И. Д. Поливариантность онтогенеза пихты сибирской / И. Д. Махатков // Бюллетень МОИП. Отдел биологический. - 1991. - Т. 96 (4). - С. 79-88. 
29. Ontogeny of a tree / O. V. Smirnova, A. A. Chistyakova, L. B. Zaugolnova, O. I. Evstigneev, R. V. Popadiouk, А. M. Romanovskii // Ботанический журнал. - 1999. - Т. 84 (12). - С. 8-20.

30. Ухваткина, О. Н. Особенности онтогенеза Picea ajanensis (Lindl. et Gord.) Fisch. ex Carr. в условиях среднегорного пояса Южного Сихотэ-Алиня / О. Н. Ухваткина, Т. А. Комарова, А. Д. Трофимова // Вестник Московского государственного университета леса. - 2010. - № 3. - С. 169-173.

31. Николаева, С. А. Онтогенез Pinus sibirica на юго-востоке Западно-Сибирской равнины / С. А. Николаева, С. Н. Велисевич, Д. А. Савчук // Journal of Siberian Federal University. Biology. - 2011. - № 4. - Р. 3-22.

32. Недосеко, О. И. Бореальные виды ив подродов Salix и Vetrix: онтоморфогенез и жизненные формы / О. И. Недосеко. - Н. Новгород : ННГУ им. Н. И. Лобаческого, 2014. - 426 с.

33. Диагнозы и ключи возрастных состояний лесных растений. Деревья и кустарники. - М. : Прометей, 1989. $102 \mathrm{c}$.

34. Чистякова А. А. Большой жизненный цикл и фитоценотическая роль липы сердцевидной (Tilia cordata Mill.) в разных частях ареала : дис. ... канд. биол. наук / А. А. Чистякова. - М. : МГПИ им. В. И. Ленина, 1978. $-256 \mathrm{c}$.

35. Воронцова Л. И. Выделение трех уровней жизненного состояния в онтогенезе особей и применение этого метода для характеристики ценопопуляций / Л. И. Воронцова, Л. Е. Гатцук, А. А. Чистякова // Подходы к изучению ценопопуляций и консорций. - М. : Прометей, 1987. - С. 7-24.

36. Романовский А. М. Поливариантность онтогенеза Picea abies (Pinaceae) в Брянском полесье / А. М. Романовский // Ботанический журнал. - 2001. - Т. 86 (8). - С. 72-85.

37. Евстигнеев О. И. Поливариантность сосны обыкновенной в Брянском полесье / О. И. Евстигнеев // Лесоведение. - 2014. - № 2. - С. 69-77.

38. Филимонова, В. Д. Биологические основы хранения желудей в зимний период / В. Д. Филимонова // Труды института леса. - М. : АН СССР, 1958. - Т. 29, вып. 1. - С. 83-132.

39. Нестерович, Н. Д. Плоды и семена лиственных древесных растений / Н. Д. Нестерович, И. И. Чекалинская, Ю. Д. Сироткин. - Минск : Наука и техника, 1967. - 286 с.

40. Thompson, K. The soil seed banks of North West Europe / K. Thompson, J. P. Bakker, R. M. Bekker. - Cambridge, 1996. $-288 \mathrm{p}$.

41. Заборовский, Е. П. Плоды и семена древесных и кустарниковых пород / Е. П. Заборовский. - М. : Гослесбумиздат, $1962 .-303 \mathrm{c}$.

42. Ильинский, А. П. Расселение растений (основные понятия и термины) / А. П. Ильинский // Природа. 1945. - № 5. - C. 45-55.

43. Артюшенко, Т. 3. Атлас по описательной морфологии растений. Плод / Т. 3. Артюшенко. - Л. : Наука, 1989. - 392 c.

44. Левина, Р. Е. Способы распространения плодов и семян / Р. Е. Левина. - М. : Изд-во МГУ, $1957 .-360$ с.

45. Левина, Р. Е. Морфология и экология плодов / Р. Е. Левина. - Л. : Наука, 1987. - 160 с.

46. Нестеров, В. Г. Общее лесоводство / В. Г. Нестеров. - М. ; Л. : Гослесбумиздат, 1949. - 664 с.

47. Декатов, Н. Е. Мероприятия по возобновлению леса при механизированных рубках / Н. Е. Декатов. - М. : Гослесбумиздат, 1961. - 279 с.

48. Денисов, А. К. Анемохория берез пушистой и бородавчатой / А. К. Денисов, С. А. Денисов, Е. К. Кудрявцев // Известия высших учебных заведений. Лесной журнал. - 1973. - № 3. - С. 6-9.

49. Лукьянец, А. И. Распространение древесных растений на промышленных отвалах Урала / А. И. Лукьянец // Экология. - 1982. - № 2. - С. 80-83.

50. Евстигнеев, О. И. Анемохория и дальность рассеивания семян деревьев восточноевропейских лесов / О. И. Евстигнеев, И. А. Мурашев, В. Н. Коротков // Лесоведение. - 2016. - № 6. В печати.

51. Образцов, Б. В. Материалы опытов и наблюдений по распространению дикими животными семян деревьев и кустарников в открытые биотопы лесостепи / Б. В. Образцов // Сообщения лаборатории лесоведения. М. : АН СССР, 1961. - Вып. 3.- С. 69-88.

52. Жмылев, П. Ю. Биоморфология растений : иллюстрированный словарь / П. Ю. Жмылев, Ю. Е. Алексеев, Е. А. Карпухина, С. А. Баландин. - М. : Изд-во МГУ, 2002. - 240 с.

53. Серебрякова, Т. И. Зародыш и проросток - начальные этапы онтогенеза цветкового растения // Ботаника: морфология и анатомия растений / Т. И. Серебрякова. - М. : Просвещение, 1988. С. - 130-151.

54. Васильченко, И. Т. Всходы деревьев и кустарников / И. Т. Васильченко. - М. ; Л.: АН СССР, 1960. - 302 с.

55. Полная энциклопедия русского сельского хозяйства и соприкасающихся с ним наук. - СПб. : Изд-во А. Ф. Девриена, 1900-1912. -Т. 1-12.

56. Деревья и кустарники СССР. - М. ; Л. : АН СССР, 1951. - Т. 2. - 612 с.

57. Киселева К. В. Морфологические отличия проростков ильма (Ulmus scabra Mill.) и вяза (Ulmus laevis Pall.) / К. В. Киселева // Биологические науки. - 1964. - № 4. - С. 103-105.

58. Буланая, М. В. Биология и фитоценотическая роль черемухи обыкновенной (Prunus padus L.) в paзных частях ареала : дис. ... канд. биол. наук / М. В. Буланая. - М. : МГПИ им. В. И. Ленина, 1989. - 200 с.

59. Правдин, Л. Ф. Ива, ее культура и использование / Л. Ф. Правдин. - М. : АН СССР, 1952. - 168 с.

60. Кондратьева-Мельвиль, Е. А. О разнолистности у сеянцев некоторых древесных растений / Е. А. Кондратьева-Мельвиль // Ботанический журнал. - 1965. - Т. 50 (5). - С. 605-613. 
61. Серебряков, И. Г. Экологическая морфология растений. Жизненные формы покрытосеменных и хвойных растений / И. Г. Серебряков. - М. : Высш. шк., 1962. - 379 с.

62. Михалевская, О. Б. Биологические особенности развития и роста дуба (Quercus robur L.) на ранних этапах онтогенеза : автореф. дис. ... канд. биол. наук / О. Б. Михалевская. - М. : МГПИ им. В. И. Ленина, 1953. $-13 \mathrm{c}$.

63. Чистякова, А. А. Дуб черешчатый / А. А. Чистякова // Диагнозы и ключи возрастных состояний лесных растений. Деревья и кустарники. - М. : Прометей, 1989. - С. 18-25.

64. Комиссаров, Д. А. Биологические основы размножения древесных растений черенками / Д. А. Комиссаров. М. : Лесная промышленность, 1964. - 292 с.

65. Ботаника: морфология и анатомия растений. - М. : Просвещение, 1988. - 479 с.

66. Леонова, Н. А. Структура ценопопуляций Ulmus glabra и Ulmus laevis в плакорных и пойменных лесах центральной России : дис. ... канд. биол. наук / Леонова Н. А. - М. : МПГУ, 1999. - 200 с.

67. Евстигнеев О. И. Световой минимум подроста деревьев хвойно-широколиственного леса // Структурнофункциональная организация и динамика растительного покрова. - Самара : ПГСГА, 2012. - С. 181-184.

68. Малкина, И. С. Фотосинтез и дыхание подроста / И. С. Малкина, Ю. Л. Цельникер, А. М. Якшина. - М. : Наука, 1970. - $181 \mathrm{c}$.

69. Цельникер, Ю. Л. Физиологические основы теневыносливости древесных растений / Ю. Л. Цельникер. M., 1978. -212 c.

70. Князева, И. Ф. Определение баланса органического вещества у саженцев клена остролистного в условиях разного затенения / И. Ф. Князева, И. С. Малкина, А. М. Якшина // Лесоведение. - 1971. - № 2. - С. 15-22.

71. Якшина, А. М. Об интенсивности дыхания корневой системы клена при разном затенении / А. М. Якшина // Физиология растений. - 1978. - Т. 25 (1). - С. 64-69.

72. Алексеев, В. А. Световой режим леса / В. А. Алексеев. - Л. : Наука, 1975. - 228 с.

73. Вальтер, Г. Растительность земного шара. Эколого-физиологическая характеристика. Леса умеренной зоны / Г. Вальтер. - М. : Прогресс, 1974. - Т. 2. - 423 с.

74. Лир, Х. Физиология древесных растений / Х. Лир, Г. Польстер, Г.-И. Фидлер. - М. : Лесная промышленность, 1974. - 424 с.

75. Евстигнеев, О. И. Особенности развития широколиственных деревьев под пологом леса при различной освещенности / О. И. Евстигнеев // Ботанический журнал. - 1988. - Т. 73 (12). - С. 1730-1736.

76. Евстигнеев, О. И. Механизмы поддержания биологического разнообразия лесных биогеоценозов : дис. ... д-ра биол. наук / О. И. Евстигнеев. - Н. Новгород : НГУ им. Н. И. Лобачевского, 2010. - 513 с.

77. Дервиз-Соколова Т. Г. Анатомо-морфологическое строение Salix polaris Wahlb. и S. phlebophylla Andress. / Т. Г. Дервиз-Соколова // Бюллетень МОИП. Отдел биологический. - 1966. - Т. 71 (2). - С. $28-38$.

78. Вегетативный лес / С. С. Пятницкий, М. П. Коваленко, Н. А. Лохматов, И. В. Туркевич, В. Г. Ступников, В. П. Сущенко, Г. П. Чони. - М. : Сельхозиздат, 1963. - 448 с.

79. Чистякова, А. А. Вяз шершавый, или ильм горный / А. А. Чистякова, И. С. Кутьина // Диагнозы и ключи возрастных состояний лесных растений. Деревья и кустарники. - М. : Прометей, 1989. - С. 82-89.

80. Лярская, Р. П. Образование придаточных почек на корнях яблони / Р. П. Лярская // Вестник Московского университета. - 1957. - № 4. - С. 53-62.

81. Лащинский, Ник. Н. Осина / Ник. Н. Лащинский // Диагнозы и ключи возрастных состояний лесных растений. Деревья и кустарники. - М. : Прометей, 1989. - С. 89-96.

82. Заугольнова, Л. Б. Анатомо-морфологическое строение листьев и почек у разных возрастных групп ясеня обыкновенного (Fraxinus excelsior L.) / Л. Б. Заугольнова // Биологические науки. - 1971. - № 9. - С. 56-64.

83. Чистякова, А. А. Бук европейский / А. А. Чистякова // Диагнозы и ключи возрастных состояний лесных растений. Деревья и кустарники. - М. : Прометей, 1989. - С. 25-35.

84. Тимофеева, Е. К. Лось (экология, распространение, хозяйственное значение) / Е. К. Тимофеева. - Л. : Издво ЛГУ, 1974. - $168 \mathrm{c.}$

85. Тимофеева, Е. К. Косуля / Е. К. Тимофеева. - Л. : Изд-во ЛГУ, 1985. - 224 с.

86. Данилкин, А. А. Оленьи (Cervidae) / А. А. Данилкин. - М. : ГЕОС, 1999. - 552 с.

87. Данилкин, А. А. Полорогие (Bovidae) / А. А. Данилкин. - М. : Товарищество научных изданий КМК, 2005. $550 \mathrm{c.}$

88. Юницкий, А. А. О возобновлении дуба «торчками» / А. А. Юницкий // Лесоведение и лесоводство. - 1927. №. 4. - С. 190-193.

89. Белостоков, Г. П. Морфогенез кустовидного подроста клена остролистного (Acer platanoides L.) / Г. П. Белостоков // Биологические науки. - 1976. - № 3. - С. 75-80.

90. Белостоков, Г. П. Формирование габитуса кустовидного подроста вяза гладкого / Г. П. Белостоков // Лесоведение. - 1981. - № 2. - С. 82-86.

91. Белостоков, Г. П. Габитус кустовидного подроста древесных растений / Г. П. Белостоков // Ботанический журнал. - 1980. - Т. 65 (3). - С. 391-404.

92. Истомина, И. И. Квазисенильность и ее роль в жизни древесных растений : автореф. дис. ... канд. биол. наук / И. И. Истомина. - М. : МГПИ им. В. И. Ленина, 1992. - 16 с.

93. Смирнова, О.В.Квазисенильность как одно из проявлений фитоценотической толерантности растений / О. В. Смирнова, А. А. Чистякова, И. И. Истомина // Журнал общей биологии. - 1984. - Т. 45 (2). C. $216-225$ 
94. Евстигнеев, О. И. Популяционные стратегии видов деревьев / О. И. Евстигнеев // Восточноевропейские леса: история в голоцене и современность. - М. : Наука, 2004. - Кн. 1. - С. 176-205.

95. Иванов, Л. А. Физиология растений / Л. А. Иванов. - Л. : Гослестехиздат, 1936. - 386 с.

96. Морозов, Г. Ф. Учение о лесе / Г. Ф. Морозов. - М. ; Л. : Гослесбумиздат, 1949. - 456 с.

97. Малкина, И. С. Связь интенсивности фотосинтеза листьев дуба с их структурой и возрастом дерева / И. С. Малкина // Лесоведение. - 1983. - № 4. - С. 68-71.

98. Цельникер, Ю. Л. Влияние возраста дерева на структуру и функцию фотосинтетического аппарата дуба черешчатого / Ю. Л. Цельникер, И. С. Малкина // Физиология растений. - 1983. - Т. 30 (2). - С. 349-354.

99. Whitehead, F. H. Growth analysis of plant. The ratio of mean relative rate of leaf area increase / F. H. Whitehead, P. J. Myerscough // New Phytol. - 1962. - Vol. 61 (3). - P. 314-321.

100. Евстигнеев, О. И. Особенность формирования кроны подроста широколиственных деревьев под пологом леса / О. И. Евстигнеев // Современные проблемы популяционной экологии, геоботаники, систематики и флористики. - Кострома : КГУ им. Н. А. Некрасова, 2011. - Т. 1.- С. 95-98.

101. Зединг, Г. Ростовые вещества растений / Г. Зединг. - М. : Иностранная литература, 1955. -388 с.

102. Левина, Р. Е. Репродуктивная биология семенных растений / Р. Е. Левина. - М. : Наука, 1981. - 96 с.

103. Лесная энциклопедия. - М. : Сов. энциклопедия, 1985. - Т. 1. - 563 с.

104. Лесная энциклопедия. - М. : Сов. энциклопедия, 1986. - Т. 2. - 631 с.

105. Гроздов, Б. В. Дендрология / Б. В. Гроздов. - М. ; Л. : Гослесбумиздат, 1960. - 355 с.

106. Шиманюк, А. П. Дендрология / А. П. Шиманюк. - М. : Лесная промышленность, 1974. - 264 с.

107. Крамер, П. Д. Физиология древесных растений / П. Д. Крамер, Т. Т. Козловский. - М. : Лесная промышленность, 1983. - 464 с.

108. Бугровский, В. В. Механизмы развития и старения отдельно растущих деревьев / В. В. Бугровский, Е. Г. Меллина, Ю. Л. Цельникер // Доклады АН СССР. - 1985. - Т. 280 (4). - С. 1020-1024.

109. Рост и газообмен $\mathrm{CO}_{2}$ у лесных деревьев / Ю. Л. Цельникер, И. С. Малкина, А. Г. Ковалев, С. Н. Чмора, В. В. Мамаев, А. Г. Молчанов. - М. : Наука, 1993. - 256 с.

110. Гордиенко, М. И. Морфологические особенности водяных побегов ясеня обыкновенного / М. И. Гордиенко, Н. М. Гордиенко // Лесоведение. - 1992. - № 3. - С. 61-68.

111. Туркевич И. В. Водяные побеги / И. В. Туркевич // Вегетативный лес. - М. : Сельхозиздат, 1963. C. $148-179$.

112. Казарян, В. О. Старение высших растений / В. О. Казарян. - М. : Наука, 1969. - 313 с.

113. Малкина, И. С. Световые кривые фотосинтеза подроста лиственных пород / И. С. Малкина // Световой режим, фотосинтез и продуктивность леса. - М. : Наука, 1967. - С. 220-231.

\section{References}

1. Korchagin A. A. Polevaja geobotanika [Field geobotany]. Moscow; Leningrad: AN SSSR, 1960, vol. 2, pp. $209-240$.

2. Harper J. L. Population biology of plants. London; New York: Academic Press, 1977, 892 p.

3. Silvertown J. W. Introduction to plant ecology. London; New York: Longman, 1982, 209 p.

4. Rabotnov T. A. Geobotanika [Geobotany]. Moscow; Leningrad: AN SSSR, 1960, vol. 6, pp. 7-204.

5. Ontogenez $i$ vozrastnoj sostav populjacij cvetkovyh rastenij [Ontogenesis and age composition of flowering plant populations]. Ed. by A. A. Uranov. Moscow: Nauka, 1967, 156 p.

6. Voprosy morfogeneza cvetkovyh rastenij i stroenija ih populjacij [Problems of morphogenesis of flowering plants and their populations' structure]. Ed. by A. A. Uranov. Moscow: Nauka, 1968, 233 p.

7. Uranov A. A. Biologicheskie nauki [Biological sciences]. 1989, no. 11, pp. 7-34.

8. Gatzuk L. E., Smirnova O. V., Vorontzova L. I., Zaugolnova L. B., Zhukova L. A. Journal of Ecology. 1980 , vol. 68 (3), pp. 675-696.

9. Shorina N. I., Smirnova O. V. Handbook of vegetation science. Part III. The population structure of vegetation. Ed. J. White. Dordrecht: Dr. W. Junk Publishers, 1985, pp. 225-240.

10. Cenopopuljacii rastenij (osnovnye ponjatija i struktura) [Coenopopulations of plants (basic concepts and structure)]. Moscow: Nauka, 1976, 217 p.

11. Zaugol'nova L. B., Zhukova L. A., Komarov A. S., Smirnova O. V. Cenopopuljacii rastenij (ocherki populjacionnoj biologii) [Coenopopulations of plants (population biology essays)]. Moscow: Nauka, 1988, 184 p.

12. Smirnova O. V., Palenova M. M., Komarov A. S. Russian Journal of Developmental Biology. 2002, vol. 33 (1), pp. 1-10 [Translated from Ontogenez. 2002, vol. 33 (1), pp. 5-15].

13. Zaugol'nova L. B. Biologicheskie nauki [Biological sciences]. 1967, no. 5, pp. 98-102.

14. Zaugol'nova L. B. Voprosy morfogeneza cvetkovyh rastenij i stroenija ih populjacij [Problems of morphogenesis of flowering plants and their populations' structure]. Moscow: Nauka, 1968, pp. 81-102.

15. Smirnova O. V., Chistjakova A. A., Ripa S. I., Lysyh N. I. Bjulleten' MOIP. Otdel biologicheskij [Bulletin of MOIP. Biological department]. 1989, vol. 94 (5), pp. 78-91.

16. Evstigneev O. I., Korotkov V. N., Bakalyna L. V. Bjulleten' MOIP. Otdel biologicheskij [Bulletin of MOIP. Biological department]. 1992, vol. 97 (2), pp. 81-89.

17. Evstigneev O. I., Voevodin P. V., Korotkov V. N., Murashev I. A. Uspehi sovremennoj biologii [Progress of modern biology]. 2013, vol. 133 (4), pp. 392-400. 
18. Vostochnoevropejskie shirokolistvennye lesa [East European broad-leaved forests]. Ed. by O. V. Smirnova. Moscow: Nauka, 1994, 364 p.

19. Vostochnoevropejskie lesa: istorija v golocene $i$ sovremennost' [East European forests: history in Holocene and modern times]. Ed. by O. V. Smirnova. Moscow: Nauka, 2004, bk. 1, 479 p.

20. Vostochnoevropejskie lesa: istorija v golocene $i$ sovremennost' [East European forests: history in Holocene and modern times]. Ed. by O. V. Smirnova. Moscow: Nauka, 2004, bk. 2, 575 p.

21. Braslavskaja T. Ju. Izvestija Samarskogo NC RAN [Proceedings of Samara SC RAS]. 2013, vol. 15 (3), pp. 10411045.

22. Bernacci L. C., Martins F. R., F. F. Maës dos Santos Acta Botanica Brasilica. 2008, vol. 22 (1), pp. $119-130$.

23. Silveira A. S., Martins F. R., Araújo F. S. Acta Oecologica. 2012, vol. 43, pp. 126-133.

24. Rosseto V., Car-neiro M. S., Ramos F. N., F. F. Maes dos Santos Acta Botanica Brasilica. 2013, vol. 27 (4), pp. 730-736.

25. Nuhimovskij Ju. D. Bjulleten' MOIP. Otdel biologicheskij [Bulletin of MOIP. Biological department]. 1971, vol. $76(2)$, pp. 105-112.

26. Chistjakova A. A. Bjulleten' MOIP. Otdel biologicheskij [Bulletin of MOIP. Biological department]. 1979, vol. 84 (1), pp. 85-98.

27. Poltinkina I. V. Bjulleten' MOIP. Otdel biologicheskij [Bulletin of MOIP. Biological department]. 1985, vol. 90 (2), pp. 79-88.

28. Mahatkov I. D. Bjulleten' MOIP. Otdel biologicheskij [Bulletin of MOIP. Biological department]. 1991, vol. 96 (4), pp. 79-88.

29. Smirnova O. V., Chistyakova A. A., Zaugolnova L. B., Evstigneev O. I., Popadiouk R. V., Romanovskii A. M. Botanicheskij zhurnal [Botanical journal]. 1999, vol. 84 (12), pp. 8-20.

30. Uhvatkina O. N., Komarova T. A., Trofimova A. D. Vestnik Moskovskogo gosudarstvennogo universiteta lesa [Bulletin of Moscow State University of Forestry]. 2010, no. 3, pp. 169-173.

31. Nikolaeva S. A., Velisevich S. N., Savchuk D. A. Journal of Siberian Federal University. Biology. 2011, no. 4, pp. 3-22.

32. Nedoseko O. I. Boreal'nye vidy iv podrodov Salix $i$ Vetrix: ontomorfogenez $i$ zhiznennye formy [Boreal species of willows of Salix and Vetrix subgenera: ontomorphogenesis and life forms]. Nizhny Novgorod: NNGU im. N. I. Lobacheskogo, 2014, 426 p.

33. Diagnozy i kljuchi vozrastnyh sostojanij lesnyh rastenij. Derev'ja i kustarniki [Diagnoses and keys of age-related states of forest plants. Trees and shrubs]. Moscow: Prometej, 1989, 102 p.

34. Chistjakova A. A. Bol'shoj zhiznennyj cikl i fitocenoticheskaja rol' lipy serdcevidnoj (Tilia cordata Mill.) v raznyh chastjah areala: dis. kand. biol. nauk [Tillet's (Tilia cordata Mill.) major life cycle and phytocoenotic role in different partsof the natural habitat: dissertation to apply for the degree of the candidate of biological sciences]. Moscow: MGPI im. V. I. Lenina, 1978, 256 p.

35. Voroncova L. I., Gatcuk L. E., Chistjakova A. A. Podhody k izucheniju cenopopuljacij i konsorcij [Approaches to studying coenopopulations and consortia]. Moscow: Prometej, 1987, pp. 7-24.

36. Romanovskij A. M. Botanicheskij zhurnal [Botanical journal]. 2001, vol. 86 (8), pp. 72-85.

37. Evstigneev O. I. Lesovedenie [Dendrology]. 2014, no. 2, pp. 69-77.

38. Filimonova V. D. Trudy instituta lesa [Proceedings of the Institute of Forestry]. Moscow: AN SSSR, 1958, vol. 29, iss. 1, pp. 83-132.

39. Nesterovich N. D., Chekalinskaja I. I., Sirotkin Ju. D. Plody i semena listvennyh drevesnyh rastenij [Foetuses and seeds of leaved woody plants]. Minsk: Nauka i tehnika, 1967, 286 p.

40. Thompson K., Bakker J. P., Bekker R. M. The soil seed banks of North West Europe. Cambridge, 1996,288 p.

41. Zaborovskij E. P. Plody i semena drevesnyh i kustarnikovyh porod [Foetuses and seeds of woody and shrubby reeds]. Moscow: Gosles-bumizdat, 1962, 303 p.

42. Il'inskij A. P. Priroda [Nature]. 1945, no. 5, pp. 45-55.

43. Artjushenko T. Z. Atlas po opisatel'noj morfologii rastenij. Plod [Atlas of descriptive morphology of plants. Foetus]. Leningrad: Nauka, 1989, 392 p.

44. Levina R. E. Sposoby rasprostranenija plodov i semjan [Ways of fetuses and seeds dissemination]. Moscow: Izd-vo MGU, 1957, 360 p.

45. Levina R. E. Morfologija i jekologija plodov [Morphology and ecology of foetuses]. Leningrad: Nauka, 1987,160 p.

46. Nesterov V. G. Obshhee lesovodstvo [General forestry]. Moscow; Leningrad: Goslesbumizdat, 1949, 664 p.

47. Dekatov N. E. Meroprijatija po vozobnovleniju lesa pri mehanizirovannyh rubkah [Forest restoration measures at mechanized cuttings]. Moscow: Goslesbumizdat, 1961, 279 p.

48. Denisov A. K., Denisov S. A., Kudrjavcev E. K. // Izvestija vysshih uchebnyh zavedenij. Lesnoj zhurnal. [University oriceedings. The journal of forests]. 1973, no. 3, pp. 6-9.

49. Luk'janec A. I. Jekologija [Ecology]. 1982, no. 2, pp. 80-83.

50. Evstigneev O. I., Murashev I. A., Korotkov V. N. Lesovedenie [Forestry]. 2016, no. 6.

51. Obrazcov B. V. Soobshhenija laboratorii lesovedenija [Proceedings of the dendrological laboratory]. Moscow: AN SSSR, 1961, iss. 3, pp. 69-88.

52. Zhmylev P. Ju., Alekseev Ju. E., Karpuhina E. A., Balandin S. A. Biomorfologija rastenij: illjustrirovannyj slovar' [Plant biomorphology: illustrated dictionary]. Moscow: Izd-vo MGU, 2002, 240 p. 
53. Serebrjakova T. I. Botanika: morfologija i anatomija rastenij [Botany: plant morphology and phytotomy]. Moscow: Prosveshhenie, 1988, pp. 130-151.

54. Vasil'chenko I. T. Vshody derev'ev i kustarnikov [Sprouts of trees and shrubs]. Moscow; Leningrad: AN SSSR, 1960, 302 p.

55. Polnaja jenciklopedija russkogo sel'skogo hozjajstva i soprikasajushhihsja s nim nauk [Complete encyclopedia of Russia agriculture and contiguous sciences]. Saint-Petersburg: Izd-vo A. F. Devriena, 1900-1912, vol. 1-12.

56. Derev'ja i kustarniki SSSR [Trees and shrubs of USSR]. Moscow; Leningrad: AN SSSR, 1951, vol. 2, 612 p.

57. Kiseleva K. V. Biologicheskie nauki [Biological sciences]. 1964, no. 4, pp. 103-105.

58. Bulanaja M. V. Biologija i fitocenoticheskaja rol' cheremuhi obyknovennoj (Prunus padus L.) v raznyh cha-stjah areala: dis. kand. biol. nauk [Biology and phytocoentotic role of bird cherry (Prunus padus L.) in different parts of the natural habitat: dissertation to apply for the degree of the candidate of biological sciences]. Moscow: MGPI im. V. I. Lenina, 1989, 200 p.

59. Pravdin L. F. Iva, ee kul'tura i ispol'zovanie [Willow, its culture and usage]. Moscow: AN SSSR, 1952, 168 p.

60. Kondrat'eva-Mel'vil' E. A. Botanicheskij zhurnal [Botanical journal]. 1965, vol. 50 (5), pp. 605-613.

61. Serebrjakov I. G. Jekologicheskaja morfologija rastenij. Zhiznennye formy pokrytosemennyh $i$ hvojnyh rastenij [Ecological morphology of plants. Life forms angiosperms and conifers]. Moscow: Vyssh. shk., 1962, 379 p.

62. Mihalevskaja O. B. Biologicheskie osobennosti razvitija i rosta duba (Quercus robur L.) na rannih jetapah ontogeneza: avtoref. dis. kand. biol. nauk [Biological features of growth and development of oaks (Quercus robur L.) at early stages of ontogenesis: author's abstract of dissertation to apply for the degree of the candidate of biological sciences]. Moscow: MGPI im. V. I. Lenina, 1953, 13 p.

63. Chistjakova A. A. Diagnozy $i$ kljuchi vozrastnyh sostojanij lesnyh rastenij. Derev'ja $i$ kustarniki [Diagnoses and keys of age-related states of forest plants. Trees and shrubs]. Moscow: Prometej, 1989, pp. 18-25.

64. Komissarov D. A. Biologicheskie osnovy razmnozhenija drevesnyh rastenij cherenkami [Biological features of woody plants propagation by cuttings]. Moscow: Lesnaja promyshlennost', 1964, $292 \mathrm{p}$.

65. Botanika: morfologija i anatomija rastenij [Botany: morphology and anatomy of plants]. Moscow: Prosveshhenie, 1988, 479 p.

66. Leonova N. A. Struktura cenopopuljacij Ulmus glabra i Ulmus laevis v plakornyh i pojmennyh lesah central'noj Rossii: dis. kand. biol. nauk [Structure of of coenopopulations Ulmus glabra i Ulmus laevis in plain and inundated forests of central Russia: dissertation to apply for the degree of the candidate of biological sciences]. Moscow: MPGU, 1999, 200 p.

67. Evstigneev O. I. Strukturno-funkcional'naja organizacija i dinamika rastitel'nogo pokrova [Structural and functional organization and dynamics of plant cover]. Samara: PGSGA, 2012, pp. 181-184.

68. Malkina I. S., Cel'niker Ju. L., Jakshina A. M. Fotosintez i dyhanie podrosta [Undergrowth photosynthesis and breathing]. Moscow: Nauka, 1970, 181 p.

69. Cel'niker Ju. L. Fiziologicheskie osnovy tenevynoslivosti drevesnyh rastenij [Physiological bases of shade tolerance of woody plants]. Moscow, 1978, 212 p.

70. Knjazeva I. F., Malkina I. S., Jakshina A. M. Lesovedenie [Dendrology]. 1971, no. 2, pp. 15-22.

71. Jakshina A. M. Fiziologija rastenij [Physiology of plants]. 1978, vol. 25 (1), pp. 64-69.

72. Alekseev V. A. Svetovoj rezhim lesa [Light conditions of forests]. Leningrad: Nauka, 1975, 228 p.

73. Val'ter G. Rastitel'nost' zemnogo shara. Jekologo-fiziologicheskaja harakteristika. Lesa umerennoj zony [Planet's vegetation. Ecological and physiological characteristics. Forests of the temperate zone]. Moscow: Progress, 1974, vol. 2, 423 p.

74. Lir H., Pol'ster G., Fidler G.-I. Fiziologija drevesnyh rastenij [Physiology of woody plants]. Moscow: Lesnaja promyshlennost', 1974, $424 \mathrm{p}$.

75. Evstigneev O. I. Botanicheskij zhurnal [Botanical journal]. 1988, vol. 73 (12), pp. 1730-1736.

76. Evstigneev O. I. Mehanizmy podderzhanija biologicheskogo raznoobrazija lesnyh biogeocenozov: dis. d-ra biol. nauk [Mechanisms of forest biogeocoenoses' biological diversity maintenance: dissertation to apply for the degree of the doctor of biological sciences]. Nizhny Novgorod: NGU im. N. I. Lobachevskogo, 2010, 513 p.

77. Derviz-Sokolova T. G. Bjulleten' MOIP. Otdel biologicheskij [Bulletin of MOIP. Biological department]. 1966, vol. 71 (2), pp. 28-38.

78. Pjatnickij S. S., Kovalenko M. P., Lohmatov N. A., Turkevich I. V., Stupnikov V. G., Sushhenko V. P., Choni G. P. Vegetativnyj les [Vegetative forest]. Moscow: Sel'hozizdat, 1963, 448 p.

79. Chistjakova A. A., Kut'ina I. S. Diagnozy i kljuchi vozrastnyh sostojanij lesnyh rastenij. Derev'ja i kustarniki [Diagnoses and keys of age-related states of forest plants. Trees and shrubs]. Moscow: Prometej, 1989, pp. 82-89.

80. Ljarskaja R. P. Vestnik Moskovskogo universiteta [Bulletin of Moscow University]. 1957, no. 4, pp. 53-62.

81. Lashhinskij Nik. N. Diagnozy i kljuchi vozrastnyh sostojanij lesnyh rastenij. Derev'ja i kustarniki [Diagnoses and keys of age-related states of forest plants. Trees and shrubs]. Moscow: Prometej, 1989, pp. 89-96.

82. Zaugol'nova L. B. Biologicheskie nauki [Biological sciences]. 1971, no. 9, pp. 56-64.

83. Chistjakova A. A. Diagnozy i kljuchi vozrastnyh sostojanij lesnyh rastenij. Derev'ja i kustarniki [Diagnoses and keys of age-related states of forest plants. Trees and shrubs]. Moscow: Prometej, 1989, pp. 25-35.

84. Timofeeva E. K. Los' (jekologija, rasprostranenie, hozjajstvennoe znachenie) [Moose (ecology, dissemination, economic improtance)]. Leningrad: Izd-vo LGU, 1974, 168 p.

85. Timofeeva E. K. Kosulja [Roe deer]. Leningrad: Izd-vo LGU, 1985, 224 p. 
86. Danilkin A. A. Olen'i (Cervidae) [Deer (Cervidae)]. Moscow: GEOS, 1999, 552 p.

87. Danilkin A. A. Polorogie (Bovidae) [Hollow-horned ruminants (Bovidae)]. Moscow: Tovarishhestvo nauchnyh izdanij KMK, 2005, 550 p.

88. Junickij A. A. Lesovedenie i lesovodstvo [Dendrology and forest management]. 1927, no. 4, pp. 190-193.

89. Belostokov G. P. Biologicheskie nauki [Biological sciences]. 1976, no. 3, pp. 75-80.

90. Belostokov G. P. Lesovedenie [Dendrology]. 1981, no. 2, pp. 82-86.

91. Belostokov G. P. Botanicheskij zhurnal [Botanical journal]. 1980, vol. 65 (3), pp. 391-404.

92. Istomina I. I. Kvazisenil'nost' i ee rol'v zhizni drevesnyh rastenij: avtoref. dis. kand. biol. nauk [Quasi-senility and its role in woody plants' life: author's abstract of dissertation to apply for the degree of the candidate of biological sciences]. Moscow: MGPI im. V. I. Lenina, 1992, 16 p.

93. Smirnova O. V., Chistjakova A. A., Istomina I. I. Zhurnal obshhej biologii [The journal of general biology]. 1984, vol. 45 (2), pp. 216-225.

94. Evstigneev O. I. Vostochnoevropejskie lesa: istorija v golocene i sovremennost' [East European forests: history in Holocene and modern times]. Moscow: Nauka, 2004, bk. 1, pp. 176-205.

95. Ivanov L. A. Fiziologija rastenij [Physiology of plants]. Leningrad: Goslestehizdat, 1936, 386 p.

96. Morozov G. F. Uchenie o lese [Forest studies]. Moscow; Leningrad: Goslesbumizdat, 1949, 456 p.

97. Malkina I. S. Lesovedenie [Dendrology]. 1983, no. 4, pp. 68-71.

98. Cel'niker Ju. L., Malkina I. S. Fiziologija rastenij [Physiology of plants]. 1983, vol. 30 (2), pp. 349-354.

99. Whitehead F. H., Myerscough P. J. New Phytol. 1962, vol. 61 (3), pp. 314-321.

100. Evstigneev O. I. Sovremennye problemy populjacionnoj jekologii, geobotaniki, sistematiki $i$ floristiki [Modern problems of population ecology, geobotany, taxonomy and floristics]. Kostroma: KGU im. N. A. Nekrasova, 2011, vol. 1, pp. 95-98.

101. Zeding G. Rostovye veshhestva rastenij [Growth components of plants]. Moscow: Inostrannaja literatura, 1955, $388 \mathrm{p}$.

102. Levina R. E. Reproduktivnaja biologija semennyh rastenij [Reproductive biology of spermaphytes]. Moscow: Nauka, 1981, $96 \mathrm{p}$

103. Lesnaja jenciklopedija [Forest encyclopedia]. Moscow: Sov. jenciklopedija, 1985, vol. 1, 563 p.

104. Lesnaja jenciklopedija [Forest encyclopedia]. Moscow: Sov. jenciklopedija, 1986, vol. 2, 631 p.

105. Grozdov B. V. Dendrologija [Dendrology]. Moscow; Leningrad: Goslesbumizdat, 1960, 355 p.

106. Shimanjuk A. P. Dendrologija [Dendrology]. Moscow: Lesnaja promyshlennost', 1974, 264 p.

107. Kramer P. D., Kozlovskij T. T. Fiziologija drevesnyh rastenij [Physiology of woody plants]. Moscow: Lesnaja promysh-lennost', 1983, $464 \mathrm{p}$.

108. Bugrovskij V. V., Mellina E. G., Cel'niker Ju. L. Doklady AN SSSR. [Reports of AS USSR]. 1985, vol. 280 (4), pp. 1020-1024.

109. Cel'niker Ju. L., Malkina I. S., Kovalev A. G., Chmora S. N., Mamaev V. V., Molchanov A. G. Rost i gazoobmen SO2 u lesnyh derev'ev [Growth and SO2 exchange of forest trees]. Moscow: Nauka, 1993, 256 p.

110. Gordienko M. I., Gordienko N. M. Lesovedenie [Dendrology]. 1992, no. 3, pp. 61-68.

111. Turkevich I. V. Vegetativnyj les [Vegetative forest]. Moscow: Sel'hozizdat, 1963, pp. 148-179.

112. Kazarjan V. O. Starenie vysshih rastenij [Aging of higher plants]. Moscow: Nauka, 1969, 313 p.

113. Malkina I. S. Svetovoj rezhim, fotosintez i produktivnost' lesa [Light conditions, photosynthesis and productivity of forests]. Moscow: Nauka, 1967, pp. 220-231. 